\title{
Consequences of Fish Kills for Long- Term Trophic Structure in Shallow Lakes: Implications for Theory and Restoration
}

\author{
Carl D. Sayer, ${ }^{1 *}$ Thomas A. Davidson,,${ }^{2,3}$ Ruth Rawcliffe,,${ }^{1}$ Peter G. Langdon, ${ }^{4}$ \\ Peter R. Leavitt, ${ }^{5}$ Georgina Cockerton, ${ }^{1}$ Neil L. Rose, ${ }^{1}$ and Toby Croft $^{4}$
}

\begin{abstract}
${ }^{1}$ Environmental Change Research Centre (ECRC), Department of Geography, University College London, Gower Street, London WC1E 6BT, UK; ${ }^{2}$ Lake Group, Department of Bioscience, Aarhus University, Vejlsøvej 25, 8600 Silkeborg, Denmark; ${ }^{3}$ Section for Ecoinformatics and Biodiversity, Department of Bioscience, Aarhus University, 8600 Aarhus, Denmark; ${ }^{4}$ Geography and Environment, University of Southampton, Highfield, Southampton SO17 1BJ, UK; ${ }^{5}$ Limnology Laboratory, Department of Biology, University of Regina, Regina, Saskatchewan S4S 0A2, Canada
\end{abstract}

\begin{abstract}
Fish kills are a common occurrence in shallow, eutrophic lakes, but their ecological consequences, especially in the long term, are poorly understood. We studied the decadal-scale response of two UK shallow lakes to fish kills using a palaeolimnological approach. Eutrophic and turbid Barningham Lake experienced two fish kills in the early 1950s and late 1970s with fish recovering after both events, whereas less eutrophic, macrophyte-dominated Wolterton Lake experienced one kill event in the early 1970s from which fish failed to recover. Our palaeo-data show fish-driven trophic cascade effects across all trophic levels (covering benthic and pelagic species) in both lakes regardless of pre-
\end{abstract}

Received 16 September 2015; accepted 15 April 2016; published online 22 July 2016

Author contributions CS conceived the study. TD contributed to study design and data analysis and undertook the cladoceran analysis. RR performed the macrofossil analysis. PGL and TC performed the chironomid analysis and interpretation. PRL performed the pigment analysis and interpretation. GC undertook the diatom analysis. NR generated and interpreted the dating data. CS wrote the paper with the assistance of TD, NR, PGL and PRL.

*Corresponding author; e-mail: c.sayer@ucl.ac.uk kill macrophyte coverage and trophic status. In turbid Barningham Lake, similar to long-term studies of biomanipulations in other eutrophic lakes, effects at the macrophyte level are shown to be temporary after the first kill (c. 20 years) and non-existent after the second kill. In plant-dominated Wolterton Lake, permanent fish disappearance failed to halt a long-term pattern of macrophyte community change (for example, loss of charophytes and over-wintering macrophyte species) symptomatic of eutrophication. Important implications for theory and restoration ecology arise from our study. Firstly, our data support ideas of slow eutrophication-driven change in shallow lakes where perturbations are not necessary prerequisites for macrophyte loss. Secondly, the study emphasises a key need for lake managers to reduce external nutrient loading if sustainable and longterm lake restoration is to be achieved. Our research highlights the enormous potential of multiindicator palaeolimnology and alludes to an important need to consider potential fish kill signatures when interpreting results.

Key words: fish kills; shallow lakes; palaeolimnology; trophic cascades; macrofossils; eutrophication; biomanipulation. 


\section{INTRODUCTION}

Mass extirpations of fish involving a species, species cohort or in some cases an entire fish population are a relatively common occurrence in eutrophic, temperate shallow lakes (Jeppesen and others 1998). Such events may be caused by a variety of factors: oxygen sags in eutrophic waters and under ice, pollution and bacterial infection (Carvalho 1994; Lewis and others 2009; Balayla and others 2010). In lakes, fish are known to affect the composition, abundance and size structure of zooplankton and invertebrate populations with cascading effects on algal abundance and community structure (Brooks and Dodson 1965; Carpenter and others 1985; Carpenter and Lodge 1986; Brönmark and Weisner 1992). In addition, changes in fish populations can also affect phytoplankton composition by influencing nutrient re-cycling rates both directly and via modification of zooplankton assemblages (Vanni and Layne 1997; Vanni and others 1997). In theory, based on available literature, a large kill of predominately zooplanktivorous fish should have significant consequences for food webs in shallow lakes, potentially leading to a temporary (if fish recolonise) or more permanent (if they do not) increase in large invertebrates, an increase in the density of large cladoceran zooplankton and consequent declines in phytoplankton abundance accompanied by shifts in species assembly. Furthermore, it is possible that fish kills and indeed recovery of fish after a kill may have important implications for aquatic macrophytes in shallow lakes, with, for example, a loss of zooplanktivorous fish leading to enhanced transparency thus favouring macrophyte expansion. Indeed increases in macrophytes have often been observed in formerly eutrophic, phytoplanktondominated lakes following biomanipulation (Meijer and others 1999; Søndergaard and others 2008; Jeppesen and others 2012).

As fish kills are mostly unpredictable, their consequences have only rarely been investigated. To compensate for this, biomanipulations and other deliberate fish manipulation projects afford a potentially analogous means of determining fish loss effects on lake ecology. With few exceptions, however, biomanipulation and fish kill studies have generally been of short duration (see summaries by Søndergaard and others 2007, 2008), whereas, due to lags associated with fish recolonisation and population development following a kill, effects on the ecosystem may last for several decades leaving a considerable mismatch of timescales (Carpenter and Leavitt 1991). Indeed, more knowledge is required on how fish kills and deliberate fish removals affect shallow lakes in the long term ( $>10$ years), especially in relation to nutrient enrichment (Søndergaard and others 2008; Jeppesen and others 2012).

Palaeolimnology permits the study of lake ecosystems over decades to millennia, and because sediments typically preserve species from all compartments of the aquatic food web, including benthic and pelagic habitats, it is possible to reconstruct changes in whole-lake trophic structure (Rawcliffe and others 2010). Thus, theories regarding lake ecosystem responses to press (for example, eutrophication, climate change) and/or pulse (for example, pollution, deliberate or natural food web manipulations) perturbations can be tested and indeed developed from long-term observations of changing system behaviour (Sayer and others 2010a). The potential for detecting fish effects on lake food webs using sediment data has been demonstrated by a number of studies involving deliberate fish introductions and biomanipulations (Leavitt and others 1994; Miskimmen and others 1995; Nykänen and others 2009; Hobbs and others 2012). For example, Leavitt and others (1989) studied the consequences of fish manipulations in two USA lakes and showed predictable changes in zooplankton body size (between Bosmina and Daphnia dominance) as a response to changing levels of planktivory. Further, Buchaca and others (2011) showed an abrupt increase in remains of planktonic cladocerans and coincident changes in algal and bacterial communities as a response to piscivorous fish introductions in Lake Furnas, Azores. Palaeolimnological studies of natural and pollution-induced fish kills are relatively rare, however (Amsinck and others 2005; Davidson and others 2005). The current study focuses on both the short- and long-term consequences of fish kill events for trophic structure and dynamics in two shallow, nutrient-enriched English lakes.

Given the need for research on fish kill influences in shallow lakes, especially in relation to long-term eutrophication forcing, we use a multiindicator palaeolimnological approach to assess the decadal-scale response of two UK shallow lakes to fish loss and consider the observed changes in the context of prevailing ecological theory and restoration practices. Both our study lakes experienced large fish kills in the recent past (1950s1970s) with fish returning in one highly eutrophic, currently macrophyte-poor lake (Barningham Lake), but not in the other less eutrophic, macro- 
phyte-rich lake (Wolterton Lake). The two main objectives of our study were to determine the responses of the two contrasting lake ecosystems to fish kills in terms of trophic structure and macrophyte community change, with considerations on the longevity and permanence of effects. Previous monitoring studies have shown fish reduction to have a variable impact at the macrophyte level with permanent macrophyte expansion generally only achieved where nutrient levels are low and with a temporary or non response of macrophytes at higher nutrient levels (Jeppesen and others 2012). Our palaeolimnological study expands on previous work by exploring the consequences of fish loss over longer timescales than even the longest of monitoring studies.

We test the following hypotheses: (i) fish kills result in trophic cascades with predictable consequences for all trophic levels (that is, increases in the abundance of plant-associated invertebrates and zoobenthos, increases in the abundance of large-bodied zooplankton, declines in phytoplankton abundance) with effects that are temporary in highly eutrophic Barningham Lake (fish return) and permanent in less eutrophic Wolterton Lake (fish do not return); (ii) fish kills promote increased macrophyte abundance where they are initially absent (Barningham) and slow down eutrophication-induced turnover where they are dominant (Wolterton) but, regardless of starting conditions, are insufficient to halt eutrophication-induced degradation in the long term.

\section{StUdy Sites}

Barningham Lake $\left(52^{\circ} 52.26^{\prime} \mathrm{N}, 1^{\circ} 11.30^{\prime} \mathrm{E}\right)$ and Wolterton Lake $\left(52^{\circ} 50.8^{\prime} \mathrm{N}, 1^{\circ} 12.35^{\prime} \mathrm{E}\right)$ are located in North Norfolk, eastern England. Both lakes were excavated for ornamental purposes in the early nineteenth centuries and have small catchments in the upper reaches of the River Bure. Barningham Lake is fed by a first-order stream and a series of ditches which drain mainly arable land. Wolterton Lake is fed by springs and ditches set in semi-improved pasture land. The lakes are low-lying (Barningham $45 \mathrm{~m}$ and Wolterton $25 \mathrm{~m}$ a.s.l.), similarly small (Barningham 2 ha. and Wolterton 4.1 ha.), shallow ( $<1.5 \mathrm{~m}$ average depth) and flatbottomed. Barningham Lake is highly eutrophic $\left(810 \mu \mathrm{g}\right.$ total phosphorus TP $\mathrm{l}^{-1}, 1.6 \mathrm{mg}$ nitrate nitrogen $\mathrm{NO}_{3}{ }^{-}-\mathrm{N}^{-1}$ ) and has a sparse, speciespoor macrophyte community dominated by filamentous algae (especially Enteromorpha intestinalis) with scattered stands of Potamogeton crispus and Zannichellia palustris. By contrast, Wolterton Lake is less eutrophic (TP $63 \mu \mathrm{g} \mathrm{l}^{-1}, \mathrm{NO}_{3}{ }^{-}-\mathrm{N} 1.3 \mathrm{mg} \mathrm{l}^{-1}$ ) and generally supports an abundant aquatic vegetation typically dominated by Potamogeton pusillus and Potamogeton pectinatus, but sometimes including Chara spp. (Sayer and others 2010c). Currently, seven fish species are known to be present in Barningham Lake: roach (Rutilus rutilus), rudd (Scardinius erythrophthalmus), European perch (Perca fluviatilis), northern pike (Esox lucius), common carp (Cyprinus carpio), tench (Tinca tinca) and European eel (Anguilla anguilla). Wolterton Lake, on the other hand, is apparently fishless as testified by three recent surveys where no fish were captured (Jones and Sayer 2003; Zambrano and others 2006; Beresford and Jones 2010).

Two major fish kills are known to have occurred in Barningham Lake. The first occurred in the early 1950s and is captured by a photograph (Figure 1) showing large numbers of dead roach (dominant) in addition to common bream (Abramis brama) and northern pike. The cause of this kill is unknown. A second major kill occurred in the late 1970s involving the mass extirpation of roach, perch, common bream and northern pike (J. Rogers pers. comm.). This was due to a pollution event involving an upstream spillage of pea silage. Following this event, fish populations are thought to have recovered due to re-stocking (species unknown). In Wolterton Lake, fish were abundant in the 1960s with "very large stocks of rudd, roach, eels, perch, pike and tench" present (Bailey 1984). By the mid1970s, however, roach, rudd and perch had mostly disappeared (C. Turnball and S. Harper, pers.

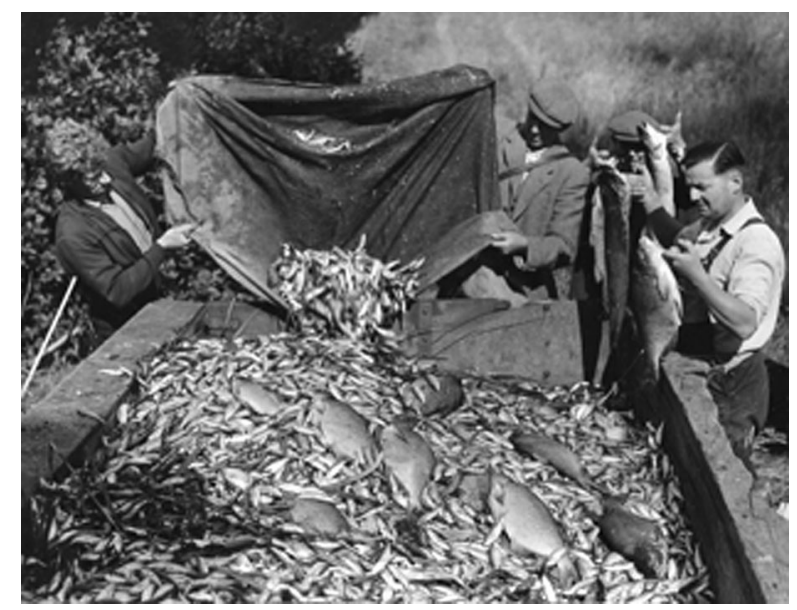

Figure 1. Dead fish recovered from Barningham Hall Lake (Norfolk, eastern England) in the early 1950s. The small and large fish in the cart are roach (Rutilus rutilus) and common bream (Abramis brama), respectively. Two northern pike (Esox lucius) are held in the air by the person third from the left. 
comm.) and, throughout the 1980s, the tench population also declined such that, by the late 1980s (Bailey 1984, 1987), fish were largely absent, as is the case today. The causes of the early 1970s fish decline at Wolterton are unknown, but a pollution event was likely partly causal (C. Turnball pers. comm.), possibly compounded by disease. Although it cannot be ruled out, anoxia-induced fish loss seems unlikely in a moderately eutrophic, macrophyte-dominated lake. Fish absence after the fish kill in Wolterton is likely due to a lack of stocking and the lake's isolation preventing natural fish re-colonisation via dispersal.

\section{MeTHODS}

\section{Core Collection and Sub-sampling}

A single sediment core was collected from each of Barningham (core code BARNl) and Wolterton (core code WOLT1) Lakes using a wide-bore (140 mm internal diameter) "Big Ben" piston corer (Patmore and others 2014) in November 2006. Cores BARNI (90 cm length) and WOLTl $(70 \mathrm{~cm}$ length) were taken from marginal locations at water depths of 0.8 and $1 \mathrm{~m}$, respectively. Big Ben was used so as to extract sufficiently large sediment volumes for the enumeration of larger, rarer fish, invertebrate and plant remains. Both cores were sliced at $1-\mathrm{cm}$ intervals. Sub-samples for algal pigment analysis were immediately placed in a cool box and frozen (at $-20^{\circ} \mathrm{C}$ ) within a few hours of collection.

\section{Sediment Dating}

Sediment chronologies were produced using a combination of radiometric, spheroidal carbonaceous particle (SCP) and event-based techniques. Sediment samples from cores BARNl and WOLTl were analysed for ${ }^{210} \mathrm{~Pb},{ }^{226} \mathrm{Ra}$ and ${ }^{137} \mathrm{Cs}$ by direct gamma assay at the UCL Environmental Radiometric Facility using an ORTEC HPGe GWL series well-type coaxial low background intrinsic germanium detector. Lead-210 was determined via its gamma emissions at $46.5 \mathrm{keV}$, and ${ }^{226} \mathrm{Ra}$ by the 295 and $352 \mathrm{keV}$ gamma rays emitted by its daughter isotope ${ }^{214} \mathrm{~Pb}$ following 3 -week storage in sealed containers to allow radioactive equilibration. Caesium-137 was measured by its emissions at $662 \mathrm{keV}$. The absolute efficiencies of the detector were determined using calibrated sources and sediment samples of known activity. Corrections were made for the effect of self absorption of lowenergy gamma rays within the samples. Radiometric dates were calculated using the CRS (constant rate of unsupported ${ }^{210} \mathrm{~Pb}$ supply) and CIC (constant initial ${ }^{210} \mathrm{~Pb}$ concentration) ${ }^{210} \mathrm{~Pb}$ dating models where appropriate (Appleby and Oldfield 1978). Factors governing model choice are discussed elsewhere (Appleby and Oldfield 1983; Appleby 2001).

SCP analysis of BARNl and WOLTl followed the procedure described in Rose (1994). Sequential treatments using nitric, hydrofluoric and hydrochloric acids removed organic, siliceous and carbonate fractions, respectively, resulting in a suspension of mainly carbonaceous material in water. A known fraction of this suspension was then evaporated onto a coverslip and the number of SCPs counted using a light microscope at $\times 400$ magnification. Criteria for SCP identification under the light microscope followed Rose (2008). SCP concentrations were expressed as the number of particles per gram dry mass of sediment $\left(\mathrm{g}^{-1} \mathrm{dm}\right)$. Analytical blanks and SCP reference material (Rose 2008) were included in each batch of sample digestions. The detection limit for the technique is typically less than $100 \mathrm{~g}^{-1} \mathrm{dm}$ and the calculated concentrations generally have an accuracy of c. $\pm 45 \mathrm{~g}^{-1} \mathrm{dm}$. Dates were ascribed to features in the SCP concentration profile as described in Rose and others (1995) and Rose and Appleby (2005). For this region of the UK, the start of the rapid increase in SCP concentration is allocated a date of $1950 \pm 10$ years, whereas the SCP concentration peak is $1970 \pm 5$ years.

As the lakes have known dates of construction, these were also used to provide a basal date for the sediment cores. Barningham Lake was constructed in 1805 and Wolterton Lake in the 1820s. Lake formation horizons were identified in the cores from available lithostratigraphic data. Such temporally well-resolved features are unusual for sediment records during this period (that is, prior to the start of the ${ }^{210} \mathrm{~Pb}$ record) and therefore provide good tie-points for the derived chronologies.

Definitive chronologies and sediment age-depth models were based on an assessment of all of the above data.

\section{Palaeolimnological Analyses}

Macrofossil analysis was undertaken on 27 and 24 targeted sediment intervals in cores BARNl and WOLTl using standard methods (Birks 2001). Between 30 and $50 \mathrm{~cm}^{3}$ of sediment, as determined by water displacement, was sieved through a series of meshes of 355 and $125 \mu \mathrm{m}$ using a gentle jet of tap water. Macro-remains of macrophytes (seeds, leaves, leaf-spines), invertebrates and fish were identified with the assistance of a dedicated 
reference collection housed at the Environmental Change Research Centre (ECRC), UCL. Historical fish presence was determined both directly using actual fish remains in the cores (scales, teeth, bones) and indirectly by the occurrence of egg cocoons of the fish leech Piscicola geometra. P. geometra is a widespread European blood-sucking ectoparasite on fish whose egg cocoons are attached to plants and readily preserved in lake sediments (Odgaard and Rasmussen 2001). The macrofossil data were expressed as no. per $100 \mathrm{~cm}^{3}$ wet sediment. In this study, "invertebrate" remains refer to Mollusca, Trychoptera, Ephemeroptera and Bryozoa and not to chironomids and Cladocera, which are considered separately.

Algal abundance and community composition were quantified from the analysis of fossil pigments from freeze-dried whole sediments. Extracts were filtered $(0.2 \mu \mathrm{m}$ pore) and evaporated to dryness using the standard methods of Leavitt and Hodgson (2001). Carotenoids, chlorophylls (Chls) and their derivatives were isolated and quantified using a high-performance liquid chromatography (HPLC) system equipped with a photo-diode array detector and calibrated with authentic standards. Pigment analysis was restricted to taxonomically diagnostic carotenoids, including those characteristic of siliceous algae and some dinoflagellates (fucoxanthin), mainly diatoms (diatoxanthin), cryptophytes (alloxanthin), chlorophytes (Chl $b$, pheophytin $b$ ), Nostocales cyanobacteria (canthaxanthin), total cyanobacteria (echinenone), purple sulphur bacteria (okenone), total algae ( $\beta$-carotene), as well as ubiquitous Chl $a$ and its derivative pheophytin $a$. Carotenoids from chlorophytes (lutein) and cyanobacteria (zeaxanthin) were inseparable and were presented together as lutein-zeaxanthin (potentially bloom-forming algae). All pigment concentrations were expressed as nmol pigment $\mathrm{g}^{-}$ ${ }^{1}$ sediment $\mathrm{C}$, a metric linearly correlated to annual algal standing stock in whole-lake calibration studies (reviewed in Leavitt and Hodgson 2001). Potential changes in the preservation environment of sediments were identified as prolonged and pronounced changes in the ratio of undegraded Chl $a$ to its chemically stable derivative pheophytin $a$. Finally, concentrations of derivatives of the UV radiation (UVR)-absorbing compound scytonemin were estimated relative to the sum of alloxanthin, diatoxanthin and lutein-zeaxanthin. This UVR index is linearly correlated to the depth of UVR penetration in whole-lake experiments and provides a metric of algal exposure to damaging levels of irradiance (Leavitt and others 1997).
Diatom analysis was undertaken using standard procedures (Battarbee and others 2001) on 28 samples from core BARNl only. A minimum of 300 valves were counted on each slide at $\times 1000 \mathrm{mag}$ nification with diatom data expressed as percentage abundances.

Analysis of cladoceran sub-fossils was carried out as outlined in Davidson and others (2007) with standard methods (Korhola and Rautio 2001) adapted to include ephippial remains from taxa (for example, Daphnia spp.) which leave few chitinous fossils (Jeppesen and others 2001). Here ephippia were enumerated from the much larger volume of sediment used in the macrofossil analysis (expressed as no. per $100 \mathrm{~cm}^{3}$ wet sediment). For chitinous cladoceran remains, samples of at least $1 \mathrm{~g}$ were heated in a deflocculating agent $(\mathrm{KOH})$ and sieved at 150 and $50 \mu \mathrm{m}$. Sub-samples of each fraction were then identified using a compound microscope at $\times 40-100$. Identifications were made with reference to Flössner (1972), Frey (1958) and Alonso (1996) with data expressed as percentage abundances. As ephippial remains from Daphnia hyalinalDaphnia longispina are difficult to separate based on morphological features, these were combined as D. hyalina agg.

Chironomids were extracted from sediments following the methods outlined in Brooks and others (2007). Samples were deflocculated in $10 \% \mathrm{KOH}$ which was heated to $75^{\circ} \mathrm{C}$ for $15 \mathrm{~min}$. The samples were then sieved through a $90 \mu \mathrm{m}$ mesh and the residue was examined under a stereo-zoom microscope at $\times 25$ magnification. Each head capsule found was picked out and mounted onto a microscope slide in a solution of Hydromatrix. Head capsules were identified following Brooks and others (2007), and the data were expressed as percentage abundances.

\section{Numerical Analysis and Data Manipulation}

Principal curves (PC) analysis (De'ath 1999) affords a generalisation of the principal axes of variation in an ordination and is a useful means of summarising patterns of species composition change in stratigraphic data (Simpson and Birks 2012). Here, we applied PC to all biological groups with different start points used for each. In general principal components analysis (PCA), axis scores based on Hellinger transformed data (Legendre and Gallagher 2001) were used to establish start points, but for the pigment data a distance-based PCA using Bray-Curtis dissimilarities was employed. LOESS was used as the smoothing function with the 
optimal degree of smoothing determined by a generalised cross-validation procedure. Given variations in the type and production rates of macrofossil remains (for example, seeds versus leaf remains) and as the data contained a high number of zeros, the macrofossil data were centred and standardised prior to Hellinger transformation. The diatom, cladoceran and chironomid data were converted to relative abundances, with cladoceran ephippia converted to weighted relative abundances following Davidson and others (2007). Those pigments showing signs of degradation (fucoxanthin, Chl a) or replicating other pigments (pheophytin a, $\beta$-carotene and myxoxanthophyll) were deleted prior to analysis. All data were square root transformed prior to analysis carried out using pcurve (Hastie and others 2011) in R version 2.15.1 (R Development Core Team 2011).

Breakpoint analysis was carried out using multivariate regression tree (MRT) analysis (De'ath 2002). Analysis was carried out for each proxy separately with date used as the explanatory variable. MRTs use binary recursive partitioning to identify points along the selected gradient (that is, date), which result in the largest difference in the two resultant groups. This can be subtly different from identifying the point of greatest change as it is dependent on the degree of change before and after the identified breakpoint. Regression trees over-fit the model to the data and need to be 'pruned' (via a cost complexity measure), based on cross-validation using a measure of prediction error (De'ath 2002). The pruning ensures that only the most significant groups and breakpoints are identified in the pruned model.

\section{RESUlts}

\section{Barningham Lake}

\section{Core Chronology}

For BARN1, unsupported ${ }^{210} \mathrm{~Pb}$ activity, calculated by subtracting ${ }^{226} \mathrm{Ra}$ activity from total ${ }^{210} \mathrm{~Pb}$, declines more or less exponentially with depth although there are possible non-monotonic features in the record. Caesium-137 activity shows a peak at $34-35 \mathrm{~cm}$ that is assumed to record the 1963 fallout maximum. However, the CRS and CIC dating models (Appleby 2001) place 1963 at 53 and $61 \mathrm{~cm}$, respectively, which differs significantly from the ${ }^{137}$ Cs record. The deeper date for 1963 from the CIC model may be due to these nonmonotonic features and hence the final radiometric chronology for BARN1 was calculated using CRS model output with the ${ }^{137}$ Cs 1963 depth used as a reference point. The SCP data show the start of the rapid concentration increase at c. $42 \mathrm{~cm}$ and the concentration peak at $32 \mathrm{~cm}$. These are ascribed dates of $1950 \pm 10$ years and $1970 \pm 5$ years showing a very good agreement with the radiometric chronology (Figure 2). Although there are no dating features prior to 1930 for this core, extrapolation of the basal sediment accumulation rate is also in reasonable agreement with a sediment depth of $89 \mathrm{~cm}$ likely representing the formation of the lake in 1805. Such extrapolations should be treated with caution, but may indicate a relatively consistent sediment accumulation rate over the first c. 100 years of the lake. The combined chronology indicates a gradually increasing rate of sedimentation after the 1950s such that most recent rates $\left(0.29 \mathrm{~g} \mathrm{~cm}^{-2} \mathrm{y}^{-1}\right)$ are around fourfold those in the 1920s, at the base of the section dateable by radiometric means.

\section{Fish Remains and Indicators}

Remains of fish in core BARNl consist of scales and scale fragments of cyprinid fish and perch, teeth of pike and undifferentiated fish bones and vertebrae (Figure 3A). Fish vertebrae are only abundant during the fish kill era $(45-20 \mathrm{~cm}=1952-1987)$, which may reflect the occurrence of dead fish close to the core site. P. geometra egg cocoons do not decline after the 1950s fish kill, but disappear completely for two consecutive sediment levels following the late 1970s $(26-22 \mathrm{~cm}=1978-1984)$ kill potentially suggesting a more complete loss of fish.

\section{Invertebrate Remains}

Invertebrate remains, consisting largely of Mollusca, occur for the first time at $40-41 \mathrm{~cm}$ (1952 \pm 6 years) as a clear response to the first fish kill (Figure 4A). All of Hippeutis complanatus, Gyraulus albus, Gyraulus crista and Pisidium spp. rise in numbers above this level peaking at $34-35 \mathrm{~cm}$ (1964 \pm 4 years), prior to a steep decline. Valvata cristata appears at $31-32 \mathrm{~cm}$ (1970 \pm 3 years) and Bithynia tentaculata at $24-25 \mathrm{~cm}$ ( $1981 \pm 2$ years). Above $20 \mathrm{~cm}$ (1987 \pm 2 years), mollusc remains are scarce, and with the exception of Pisidium spp. and $B$. tentaculata, all other species disappear. Major directional shifts were evident in the invertebrate PC after the 1950s fish kill, with significant regression tree breakpoints for 1944, 1966 and 1973 (Figure 10A). 


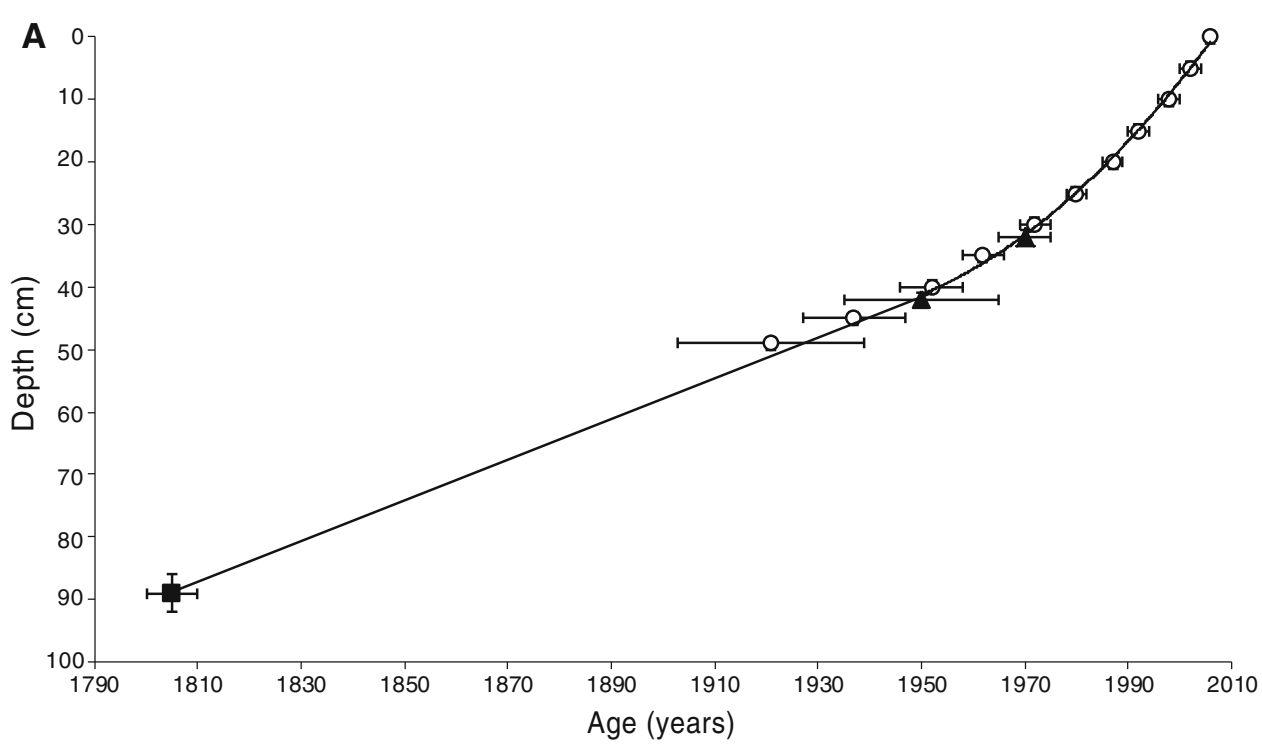

Figure 2. Age-depth relations for core BARNl in Barningham Lake (A) and core WOLTI in Wolterton Lake $(\mathbf{B})$. Black boxes represent points of lake formation as determined from lithostratigraphic data; open circles indicate radiometric dates and solid triangles indicate SCP-derived dates. Line indicates the age-depth model used in this paper.

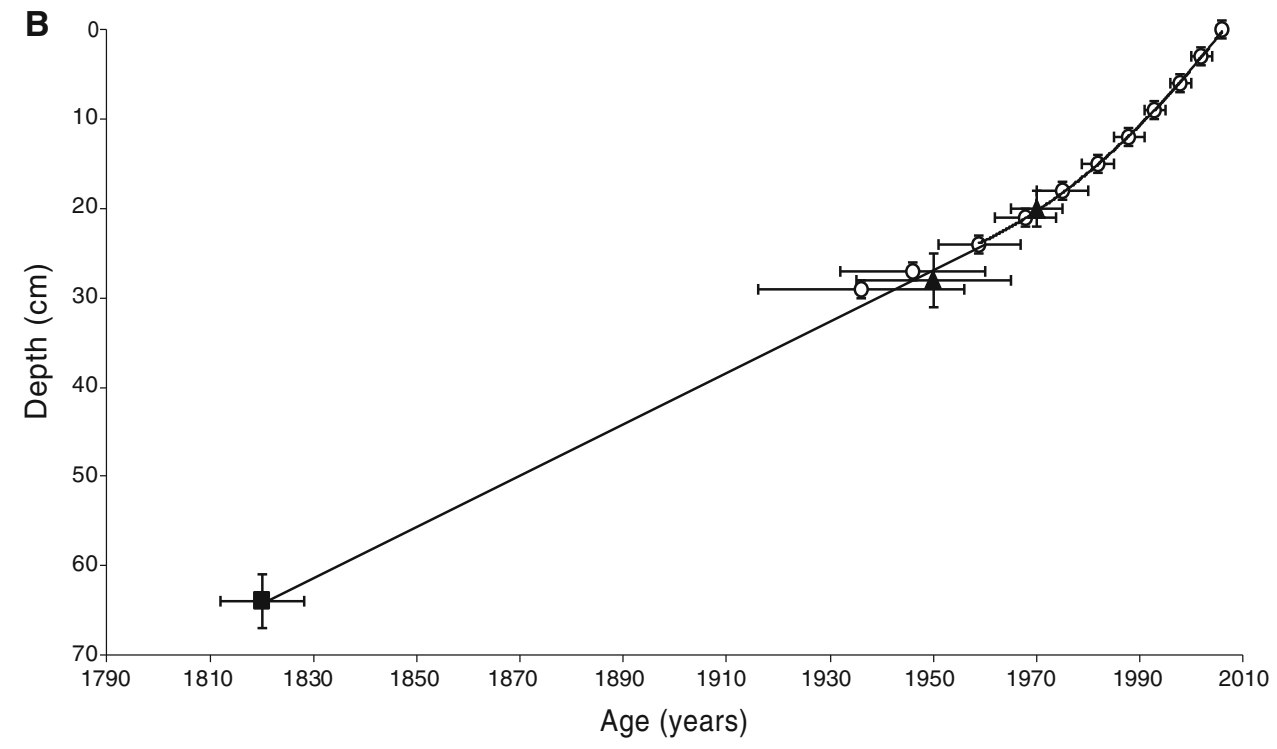

\section{Chironomid Remains}

The basal section of the chironomid stratigraphy (Figure 5A), prior to the early 1950s fish kill, is dominated by taxa typically associated with eutrophic lakes, such as Cricotopus intersectus type, Glyptotendipes pallens type and Chironomus plumosus type (Brodersen and others 2001; Ruiz and others 2006; Langdon and others 2010). At around the time of the first fish kill $(40 \mathrm{~cm}=1952 \pm 4$ years $)$, there is a gradual shift towards C. plumosus-type and Tanytarsus mendax-type dominance, whereas $C$. intersectus type and G. pallens type are reduced to minor components of the chironomid community and never recover to pre-kill numbers. The chironomid PC exhibits a gradual change with little obvious evidence of a fish kill signal, although a significant regression tree breakpoint is evident during the fish kills period for 1966 (Figure 10A).

\section{Zooplankton Remains}

Prior to the early 1950s, fish kill in Barningham dominance by Bosmina longirostris combined with low contributions from plant-associated species strongly suggests a eutrophic, largely plant-free lake. The 1950s fish kill is clearly marked in the Barningham cladoceran data (Figure 6A) by the commencement of a steep decline in B. longirostris remains and increasing concentrations of Simocephalus sp. ephippia from around $40 \mathrm{~cm}$ (1952 \pm 6 years). A further fish kill-type signature occurs at $34 \mathrm{~cm}$, where there is a sudden increase in $D$. hyalina and first appearance of $D$. pulex. This corresponds to a date of $1964 \pm 4$ years, perhaps suggesting a hitherto unrecorded, additional decline in fish. The late 1970s kill is again clearly

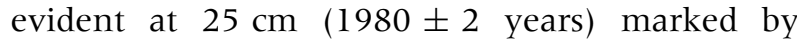
a sudden increase in $D$. magna and peaks in 

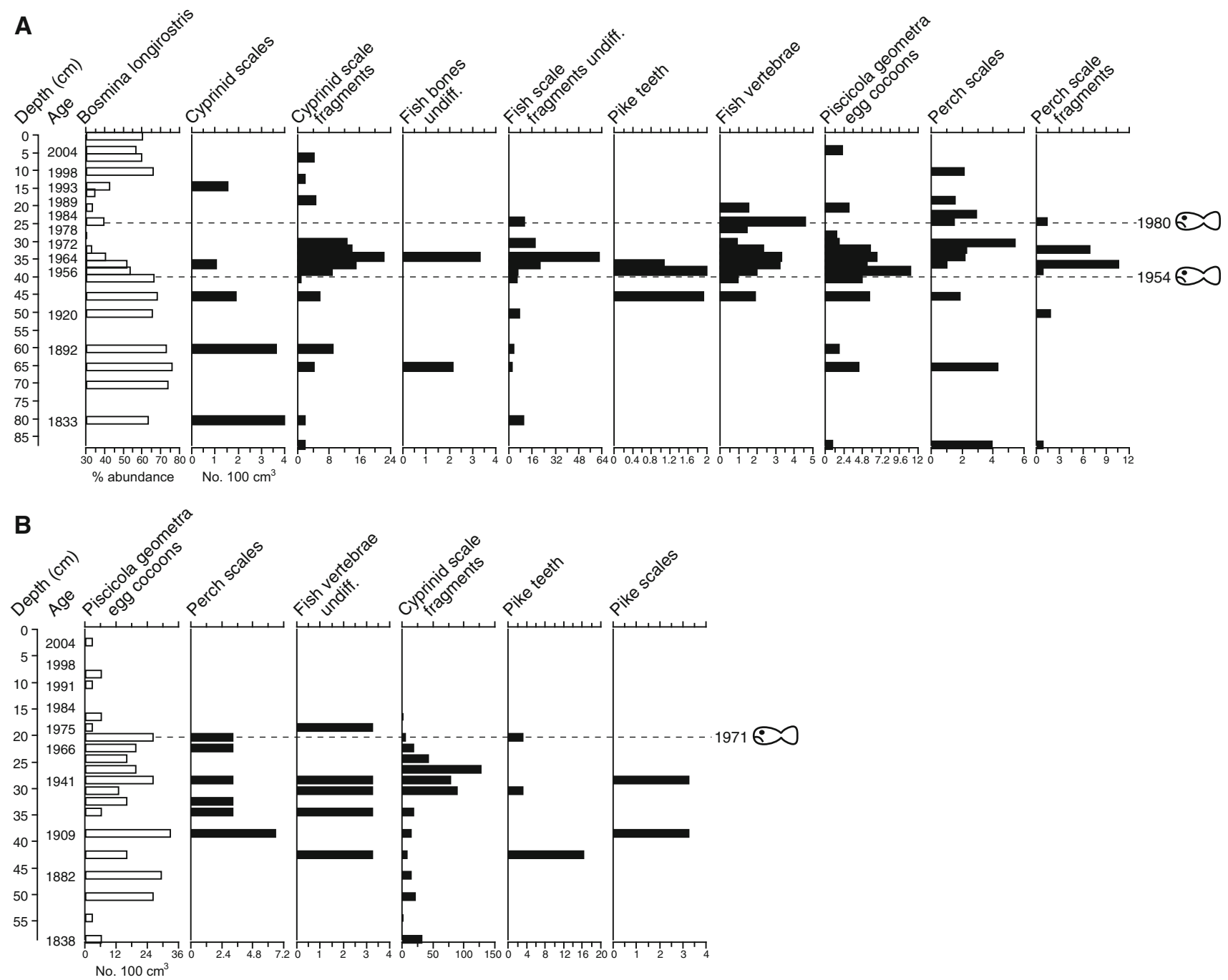

Figure 3. Fish remains and fish presence indicators (Piscicola geometra egg cocoons) in core BARNl from Barningham Lake (A) and core WOLTl from Wolterton Lake (B). Fish kill events (c. early 1950s and late 1970s in Barningham Lake and early 1970s in Wolterton Lake) are indicated by "sad fish" symbols.

Simocephalus and Leydigia spp. ephippia. After this later kill, there are declines in D. hyalina agg., $D$. magna and Simocephalus sp. and a concomitant return of $B$. longirostris dominance providing clear evidence of fish recovery. The cladoceran remains strongly suggest an increase in macrophyte cover following the early 1950s kill with an increase in the plant-associated Graptoleberis testudinaria, along with smaller increases in Chydorus sphaericus and Eurycercus lamellatus. These taxa suggest that macrophytes, or at least significant benthic primary production, occurred at the site until the late 1980s, after which declines in G. testudinaria suggest a lower abundance of plants. Major shifts in the cladoceran PC are associated with both the early 1950s and late 1970s kills with significant regres- sion tree breakpoints identified for 1958 and 1979, respectively (Figure 10A).

\section{Macrophyte Remains}

Prior to the fish kills, and typical of a highly eutrophic largely plant-free lake, remains of aquatic macrophytes are generally sparse and sporadic in core BARN1 (Figure 7A), being restricted to a few spines from $C$. demersum and seed fragments from Nymphaea alba. At $46 \mathrm{~cm}$ (1936 \pm 12 years), just prior to the fish kills period, both P. crispus turion teeth and undifferentiated Potamogeton seed fragments (likely from P. crispus) occur for the first time. Then, following the early 1950s fish kill, there is a sharp rise in $C$. demersum, continued 

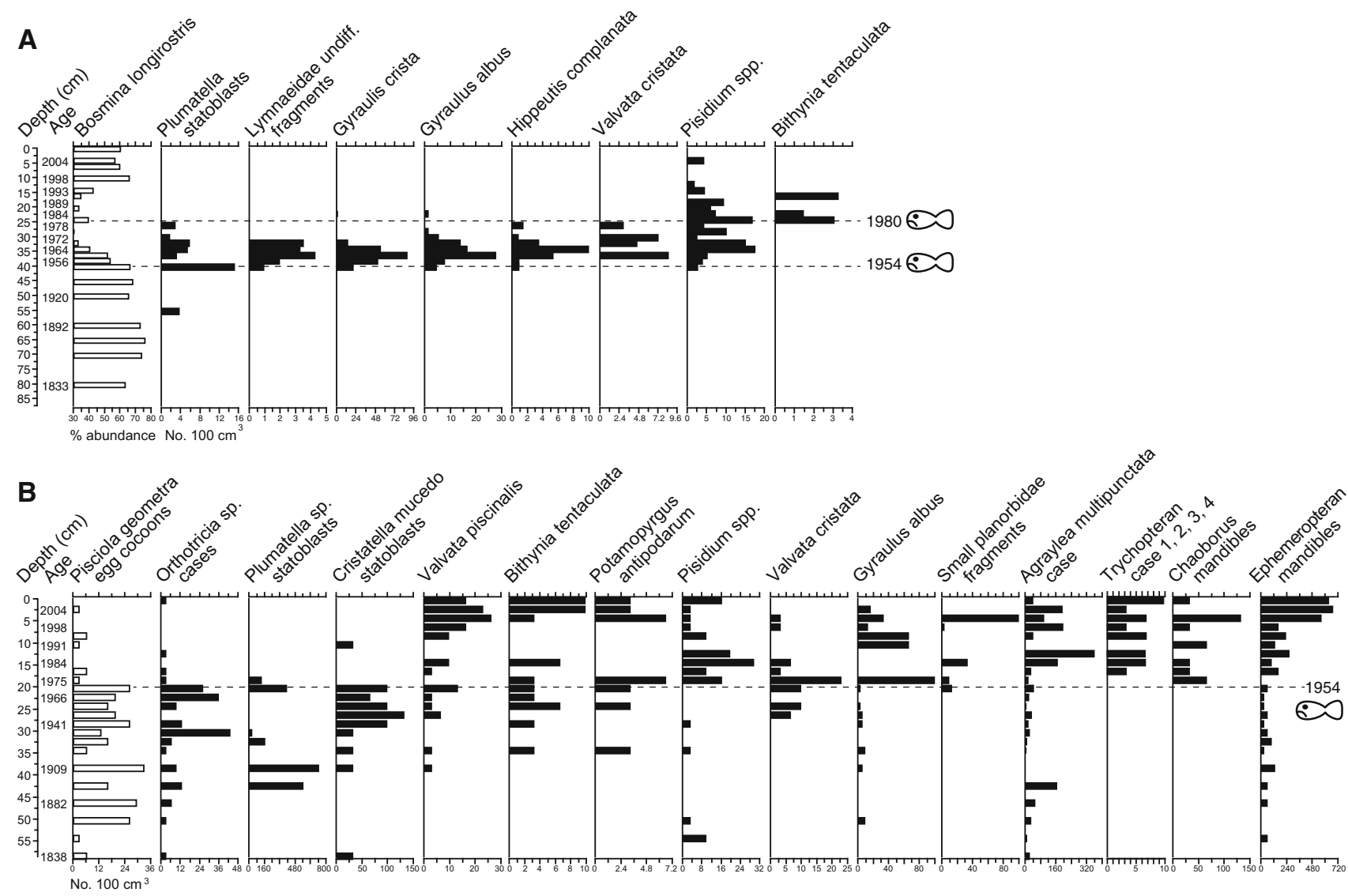

Figure 4. Summary invertebrate stratigraphy for core BARNl from Barningham Lake (A) and core WOLTl from Wolterton Lake (B). Fish kill events (c. early 1950s and late 1970s in Barningham Lake and early 1970s in Wolterton Lake) are indicated by "sad fish" symbols. The Trychopteran case plot in Wolterton is an amalgamation of 4 case morphotypes.

presence of $P$. crispus, first appearance of Ranunculus sect. Batrachium remains and more consistent presence of $Z$. palustris suggesting a more abundant submerged vegetation. C. demersum, Potamogeton undiff. and Z. palustris disappear above $25 \mathrm{~cm}$ ( $1980 \pm 2$ years) and thereafter macrophyte remains are scarce. Callitriche sp. seeds occur for the first time at $21-22 \mathrm{~cm}$ (1986 \pm 2 years) with a major peak at $10-11 \mathrm{~cm}$ (1996 \pm 2 years). Similar to the invertebrates, major directional shifts in the macrophyte PC are evident after the 1950s kill, although the only significant regression tree breakpoint occurs much earlier in 1928 associated with the first major appearance of macrophyte remains, especially Potamogeton spp. (Figure 10A).

\section{Algal Pigments}

Throughout the sediment profile, pigments are generally indicative of a eutrophic, shallow lake. Initial fossil pigment assemblages in Barningham include colonial (myxoxanthophyll) and $\mathrm{N}_{2}$-fixing cyanobacteria (aphanizophyll), as well as elevated abundances of diatoms (diatoxanthin) and cryptophytes (alloxanthin) (Figure 8A). Above $75 \mathrm{~cm}$ (c. 1848), aphanizophyll and myxoxanthophyll and several other pigments decline with the former undetected after this point. The fish kills period is marked by increases in chlorophytes-cyanobacteria (lutein-zeaxanthin), myxoxanthophyll and to a lesser extent diatoxanthin and chlorophytes (pheophytin $b$ ), with all of these pigments declining above about $19 \mathrm{~cm}$ (1988 \pm 2 years) likely associated with major fish re-colonisation subsequent to the late 1970s fish kill. Other pigments increase after this point including ubiquitous $\mathrm{Chl} a$, labile fucoxanthin from siliceous algae and UVR-indicator compounds. The pigment PC data are characterised by a "hump" of higher values over the fish kills period with a significant breakpoint identified for 1984 (although a much earlier breakpoint occurred at c. 1839) just after the second kill (Figure 10A). 

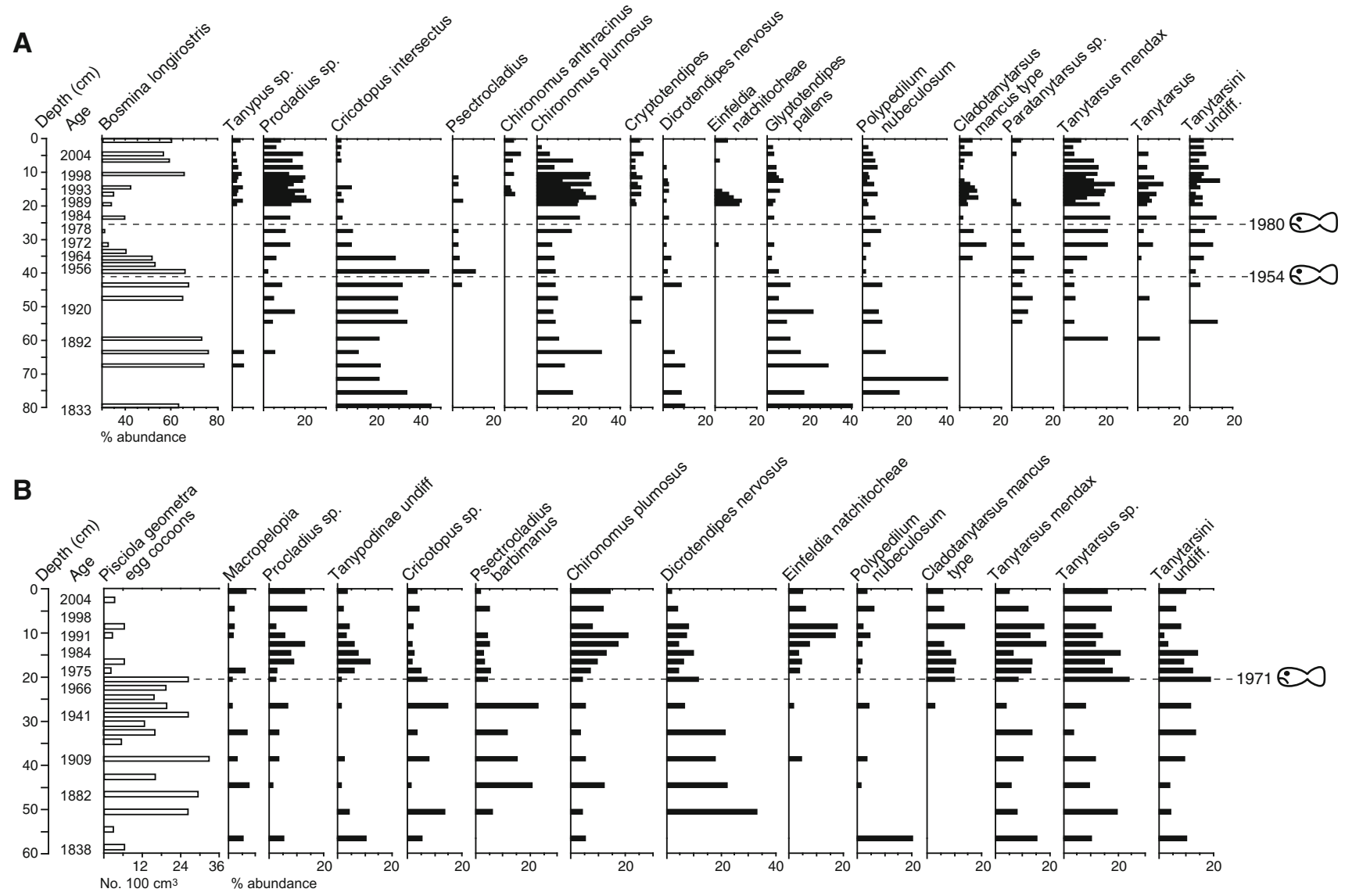

Figure 5. Summary chironomid stratigraphy for core BARNl from Barningham Lake (A) and core WOLTl from Wolterton Lake (B). Fish kill events (c. early 1950s and late 1970s in Barningham Lake and early 1970s in Wolterton Lake) are indicated by "sad fish" symbols.

\section{Diatom Remains}

Below $75 \mathrm{~cm}$ (c. 1848), diatom assemblages are dominated by epi-benthic species of Staurosira, Staurosirella and Pseudostaurosira (formerly Fragilaria spp.), with high percentages of the planktonic diatoms Cyclostephanos dubius and Stephanodiscus hantzschii suggesting eutrophic conditions (Figure 9). Above $75 \mathrm{~cm}, S$. hantzschii disappears and $C$. dubius increases attaining a peak at $54-55 \mathrm{~cm}$ (c. 1911), where it co-dominates with species in the Staurosira-Staurosirella-Pseudostaurosira complex. Above $43 \mathrm{~cm}$ (1944 \pm 8 years), just before the major changes in the Cladocera indicative of the first fish kill, there is a sharp decline in $C$. dubius coincident with increases in Staurosira construens var. venter, Pseudostaurosira brevistriata and Amphora ovalis. A significant regression tree break (for 1941) marks this change, although the PC also shows a substantial change (not associated with a significant breakpoint) associated with the early 1950s kill (Figure 10A). The reduction in C. dubius persists until the core top, with a slight upturn evident above $20 \mathrm{~cm}$ (1987 \pm 2 years).

\section{Wolterton Lake}

\section{Core Chronology}

For WOLT1, the pattern of unsupported ${ }^{210} \mathrm{~Pb}$ activity is quite unusual, declining with depth from the surface to $45-46 \mathrm{~cm}$, followed by a significant increase at the base. However, ${ }^{137} \mathrm{Cs}$ activity shows a relatively well-resolved peak at $22-23 \mathrm{~cm}$, assumed to indicate 1963. Because of the unusual ${ }^{210} \mathrm{~Pb}$ record, the CRS dating model misplaces 1963 and hence the ${ }^{210} \mathrm{~Pb}$ chronology is corrected using the ${ }^{137} \mathrm{Cs}$ date as a reference point. The SCP data show a rapid concentration increase at $28 \mathrm{~cm}$ and a concentration peak at $20 \mathrm{~cm}$, and these are ascribed dates of $1950 \pm 10$ and $1970 \pm 5$ years, respectively. As with BARN1, these SCP dates show a good agreement with the radiometric chronology and extrapolated basal sediment accumulation 

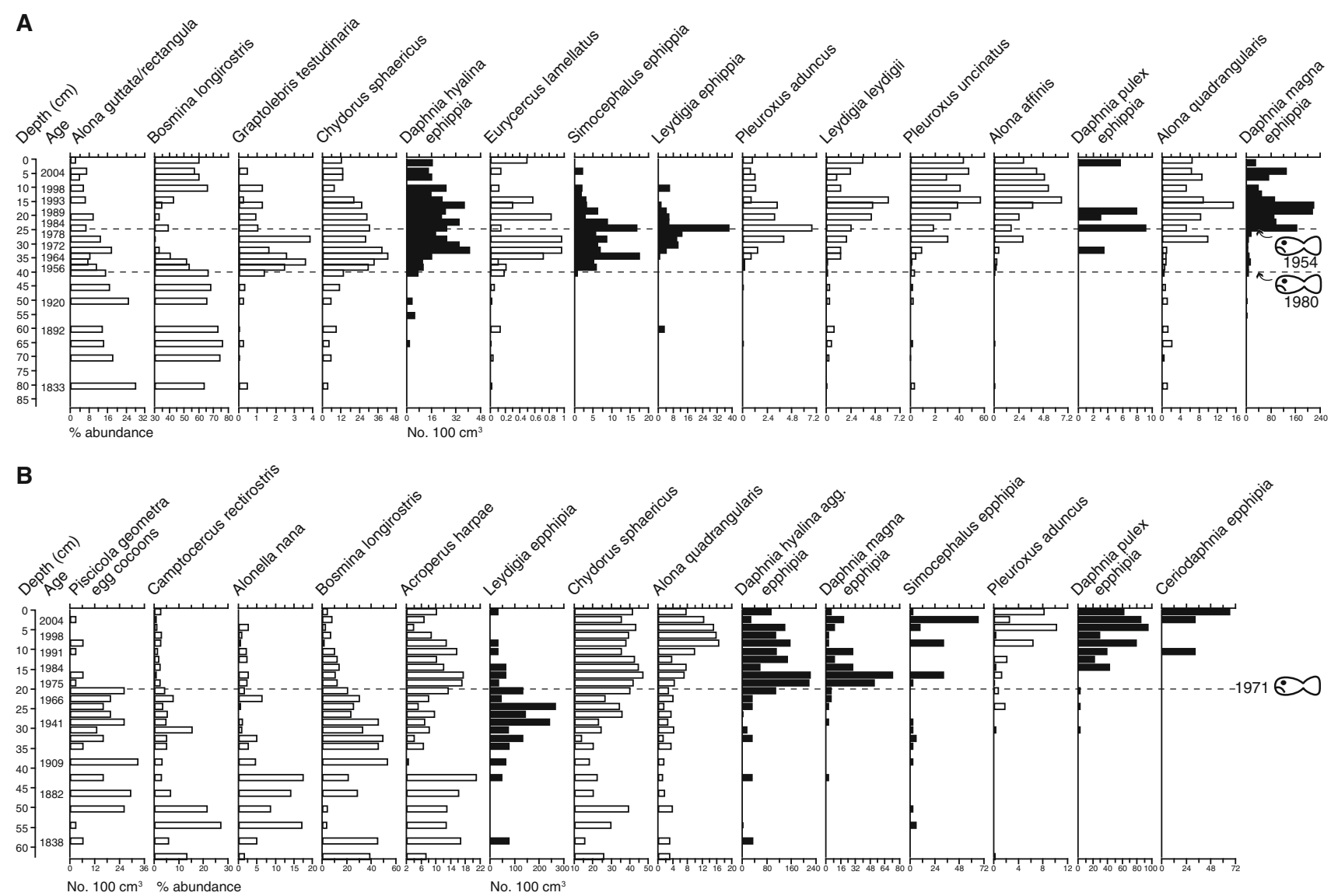

Figure 6. Summary cladoceran stratigraphy for core BARN1 from Barningham Lake (A) and core WOLT1 from Wolterton Lake (B). Ephippial remains (No. $100 \mathrm{~cm}^{3}$ ) are shown using filled bars and chitinous remains (\% relative abundance) by open bars. Fish kill events (c. early 1950s and late 1970s in Barningham Lake and early 1970s in Wolterton Lake) are indicated by "sad fish" symbols.

rates also agree reasonably with the 1820s lake formation horizon at about $65 \mathrm{~cm}$ (Figure 2B). The combined chronology indicates a steady rate of sedimentation up to the 1960 s after which rates accelerate to a most recent (2006) value of $0.18 \mathrm{~g} \mathrm{~cm}^{-2} \mathrm{y}^{-1}$, around three times higher than in the 1930s at the base of the radiometrically dated section.

\section{Fish Remains and Indicators}

Fish debris was abundant in core WOLTl (Figure $3 \mathrm{~B}$ ) consisting of scale fragments of cyprinid fish, scales of perch, scales and teeth of pike and undifferentiated fish vertebrae. Consistent with the known loss of fish from Wolterton Lake in the early 1970 s, both fish remains and P. geometra egg cocoons decline sharply above $20 \mathrm{~cm} \quad(1971 \pm 5$ years). Just one cyprinid scale fragment was recorded above this level, although P. geometra egg cocoons continue to occur sporadically. Although the former is presumably due to sediment resus- pension as opposed to fish presence, the latter may be due to P. geometra shifting host from fish to amphibians, a known phenomenon (Sawyer 1986).

\section{Invertebrate Remains}

Core WOLTl preserves a rich record of invertebrates $(20+$ species $)$ suggestive of macrophytedominated conditions throughout its history. The major change in the invertebrate stratigraphy coincides with the early 1970s fish kill (Figure 4B) as reflected by a major change in the $\mathrm{PC}$ and a significant regression tree breakpoint in 1968 (Figure 10B). Before the kill, invertebrate remains are much sparser with dominance by bryozoans (Plumatella spp. and Cristatella mucedo), the trichopterans Orthotricia sp. and Agralea multipunctata (although the latter is only abundant between 51 and $42 \mathrm{~cm} \mathrm{c.} \mathrm{1866-1897)} \mathrm{and} \mathrm{a} \mathrm{few} \mathrm{species} \mathrm{of}$ Mollusca, especially B. tentaculata and Potamopyrgus antipodarum. After the kill, numbers of several 

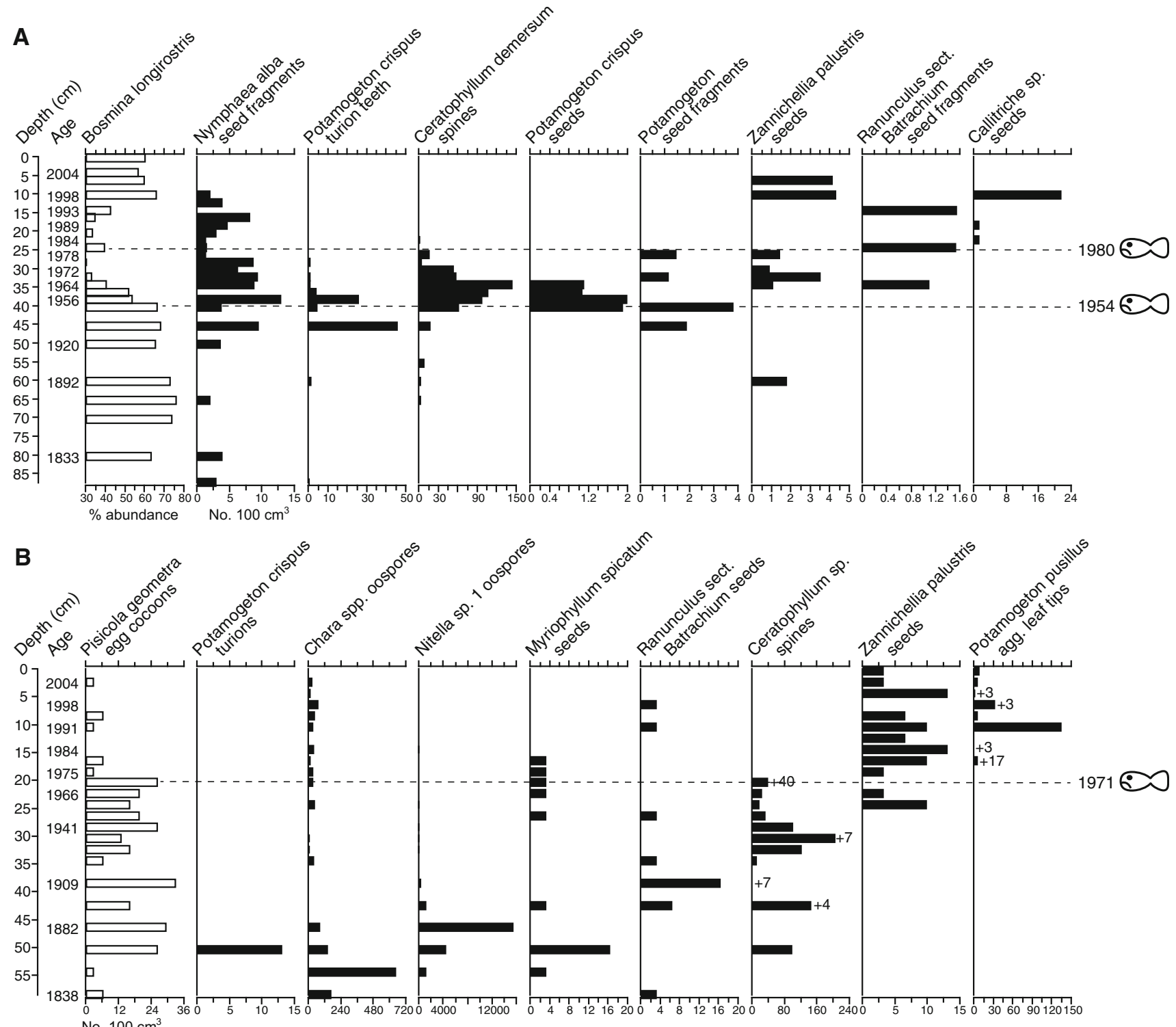

Figure 7. Macrophyte macrofossil stratigraphy of core BARNl from Barningham Lake (A) and core WOLTl from Wolterton Lake (B). Fish kill events (c. early 1950s and late 1970s in Barningham Lake and early 1970s in Wolterton Lake) are indicated by "sad fish" symbols. Numbers of Ceratophyllum demersum seeds and Potamogeton pusillus agg. seeds are given after + symbols.

invertebrate taxa sparsely present or absent before this point increase, including the dipteran Chaoborus sp., the molluscs Pisidium spp., Valvata piscinalis and G. albus, and Ephemeroptera and Trychoptera spp. (A. multipunctata and multiple $(n=4)$ case types suggests the occurrence of several species).

\section{Chironomid Remains}

In WOLT1, the chironomids (Figure 5B) show a gradual long-term shift with plant-associated gen- era such as Psectrocladius, Cricotopus and Dicrotendipes dominating the lower sections of the sequence, but showing a decline from 60 to $25 \mathrm{~cm}$. The major change in chironomid taxa occurs between 25 and $20 \mathrm{~cm}$ (1956-1971) encompassing the time of the early 1970s fish kill as reflected by a major change in the PCs and a significant regression tree breakpoint for 1973 (Figure 10B). The aforementioned taxa decline over this section, while other taxa, such as C. plumosus type, T. medax type, Einfeldia natchitocheae type and Cladotanytarsus mancus type, which are typical of more eutrophic lakes, increase 

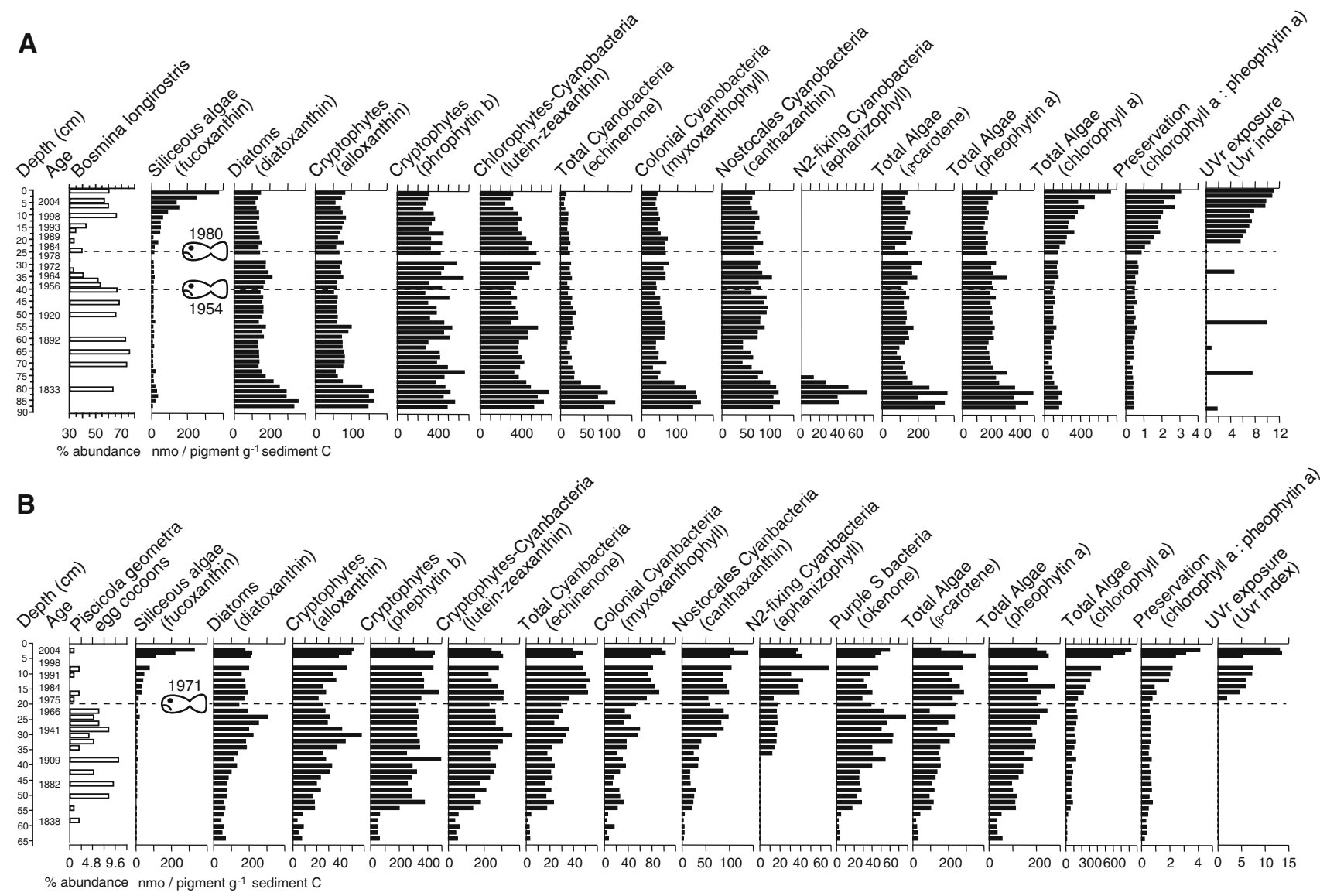

Figure 8. Summary pigment stratigraphy of core BARNl from Barningham Lake (A) and core WOLTl from Wolterton Lake (B). Fish kill events (c. early 1950s and late 1970s in Barningham Lake and early 1970s in Wolterton Lake) are indicated by "sad fish" symbols.

in abundance and continue to dominate the sequence to the core surface.

\section{Zooplankton Remains}

A diverse record of changing cladoceran assembly is preserved in core WOLTl (Figure 6B). Major changes occur coincident with the early 1970s fish kill as reflected by the PC and a significant regression tree breakpoint for 1973 (Figure 10B). Before the kill, assemblages are dominated by plant-associated cladocerans (especially Acroperus harpae and $C$. sphaericus), and the pelagic $B$. longirostris and Daphnia spp., in particular, are sparsely present suggesting macrophyte dominance. Post-kill, several species undergo a dramatic increase, particularly D. hyalina agg., D. magna and D. pulex, all of which remain abundant until the core top.

\section{Macrophyte Remains}

The plant macrofossil record from WOLTl (Figure 7B) shows step-wise community changes over time that are generally indicative of progressive eutrophication. Below $45 \mathrm{~cm}$ (c. 1886), there is dominance by oospores of Chara and Nitella spp. (likely including multiple Chara species) and seeds of Myriophyllum spicatum. After this point, there are successive peaks in $R$. sect. Batrachium seeds (38$39 \mathrm{~cm}$, c. 1909), C. demersum spines $(30-31 \mathrm{~cm}, \mathrm{c}$. 1938) and later $C$. demersum seed remains (20$21 \mathrm{~cm}, 1971 \pm 5$ years), followed by a shift to co-dominance of Z . palustris and P. pusillus above $17-18 \mathrm{~cm}$ (1978 \pm 4 years). The macrophyte PC shows increased change associated with the fish kill, although the only significant regression tree breakpoint occurs for 1903 (Figure 10B).

\section{Algal Pigments}

Concentrations of most pigments increase following the formation of Wolterton Lake and reach stable values during the early 20th century (Figure 8B). Overall, the lake appears to have been relatively productive over much of its history, with elevated concentrations of carotenoids from colonial 


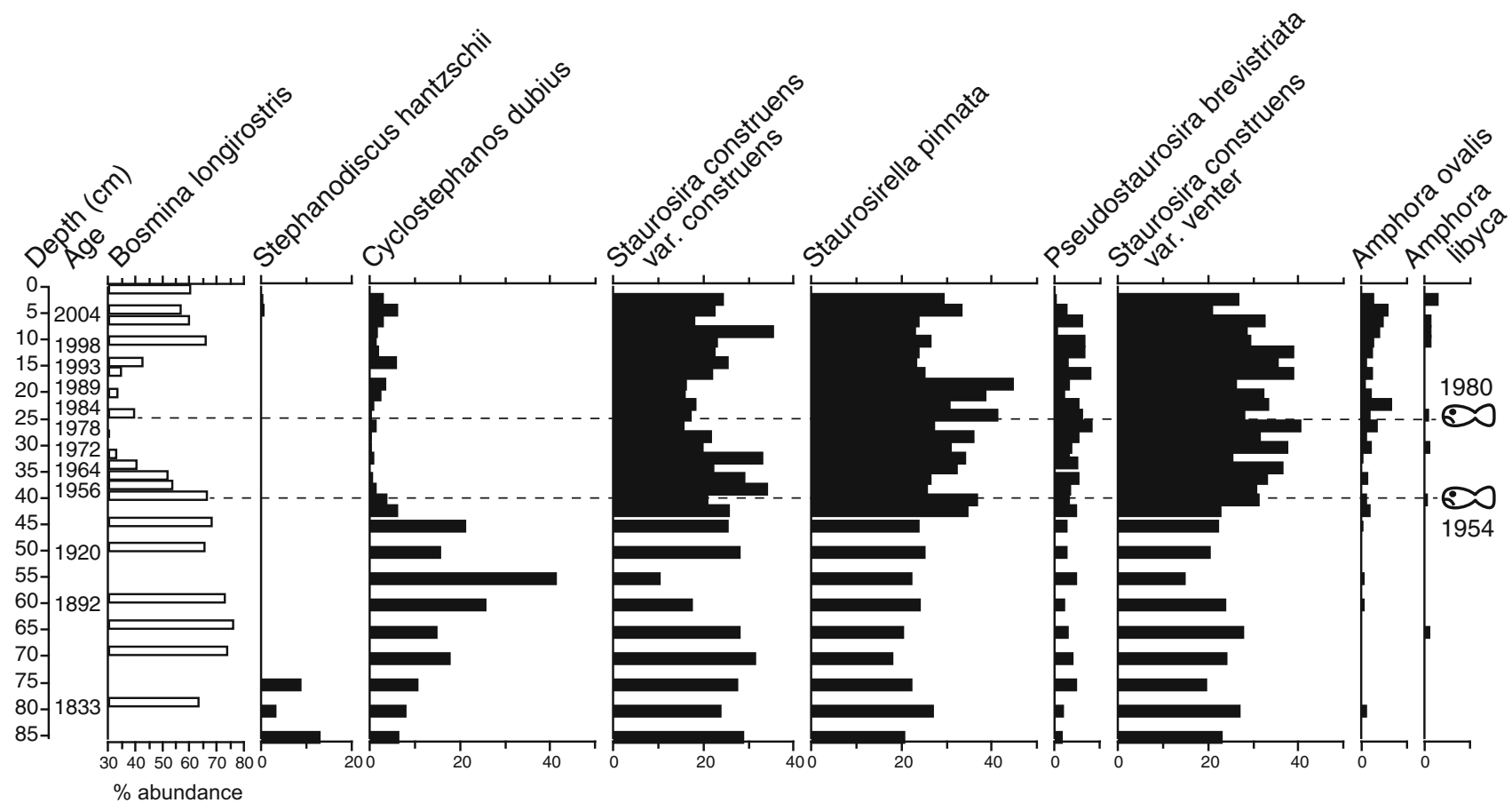

Figure 9. Summary diatom stratigraphy of core BARN1 from Barningham Lake. Fish kill events (c. early 1950s and late 1970s) are indicated by "sad fish" symbols.

(myxoxanthophyll, canthaxanthin) cyanobacteria. Ratios of Chl a:pheophytin $a$ increase fourfold following the early 1970s fish kill suggesting improved preservation. Equally, concentrations of cyanobacterial pigments increase (up to $200 \%$ ) in a staggered way after the kill: total cyanobacteria (echinone) and myxoxanthophyll above $21 \mathrm{~cm} \quad(=1971 \pm$ 5 years) and aphanizophyll above $18 \mathrm{~cm}(=1976 \pm$ 4 years). This suggests elevated production of bluegreen algae. Although absolute values of the UVR index are modest (compare Leavitt and others 1997), a marked increase in this parameter after the loss of fish suggests an increase in water transparency. A substantial change in the pigments' PC and an associated significant regression tree breakpoint (for 1980 ) occurs in the early 1980s, a few years after the fish kill (Figure 10B).

\section{Discussion}

\section{Detecting the Fish Kills}

Although fish kill signatures can be seen across multiple biological groups, they are most clearly detected by the Cladocera, especially Daphnia spp. and B. longirostris. In Wolterton, an early 1970s fish disappearance is elegantly recorded by a dramatic post-1971 increase in large Daphnia spp., a decline in $B$. longirostris and by a major change in the cladoceran PC (Figure 10B). In Barningham, the data suggest the occurrence of two fish kills as supported by the available historical evidence. The first early 1950s kill is clearly represented in the Cladocera by increases in D. hyalina agg. and Simocephalus spp. ephippia and, similar to Wolterton, a synchronous decline in $B$. longirostris. In contrast to Wolterton, D. magna did not increase at this point, likely due to high plant densities following the kill (see discussion below) and/or an incomplete loss of fish and thus some level of fish predation. Support for the latter idea of a partial fish kill in Barningham comes from the occurrence of perch scales in the BARN1 core prior to the 1950s, combined with an absence of this species in the 1950s fish kill photograph (Figure 1). Thus, although roach, common bream and pike were likely extirpated in the 1950s (all in the photograph), perch probably survived. In addition, persistence over the 1950s-1970s of cocoons from the fish leach $P$. geometra suggests a continued occurrence of fish hosts. The second historically documented late 1970s fish kill in Barningham is clearly marked by a substantial increase in D. magna at $25 \mathrm{~cm}$ (1980 \pm 2 years) . 

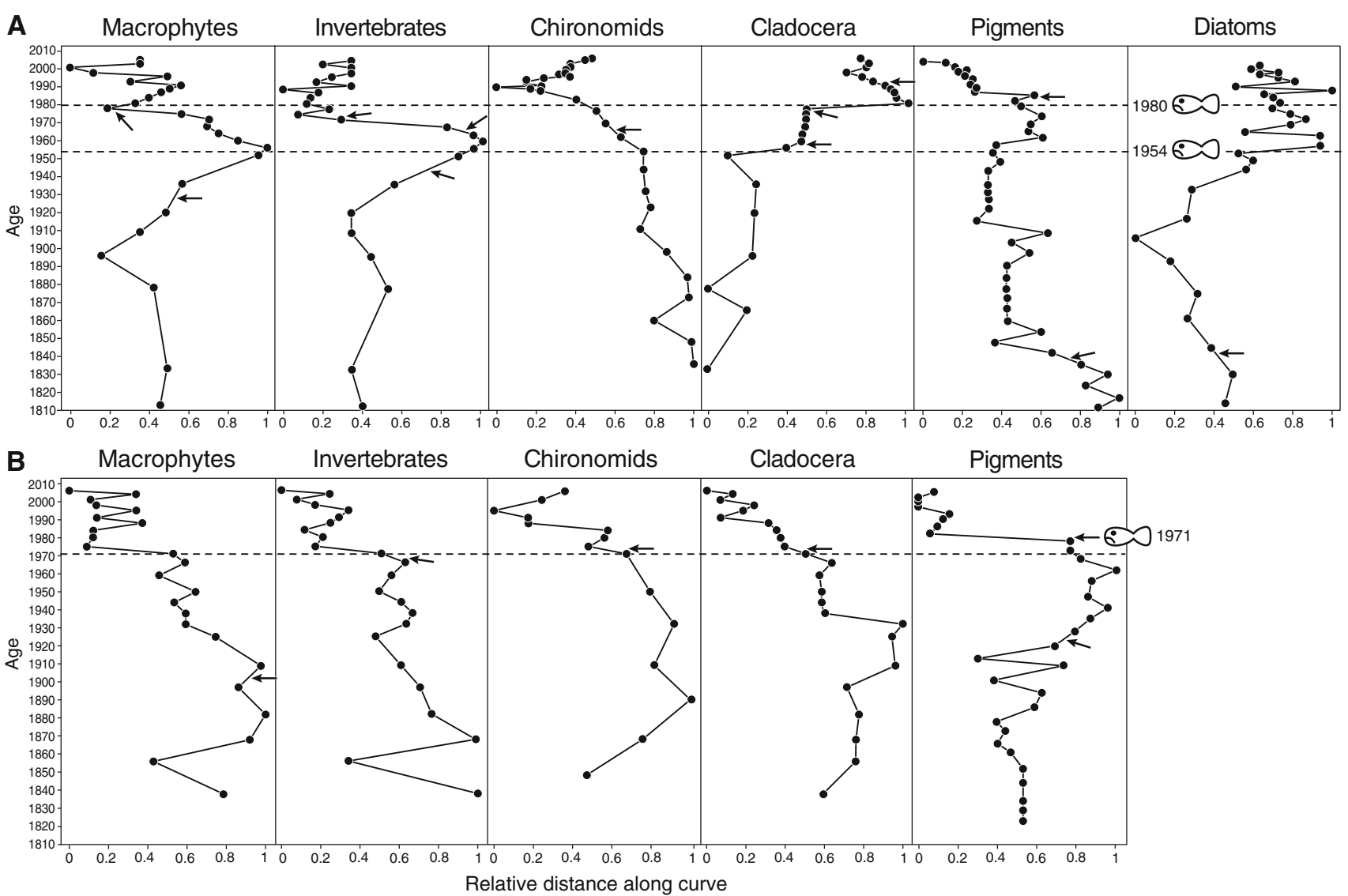

Figure 10. Principle curves (PC) plots of key fossil groups for core BARNl from Barningham Lake (A) and core WOLTl from Wolterton Lake (B). Fish kill events (c. early 1950s and late 1970s in Barningham Lake and early 1970s in Wolterton Lake) are indicated by "sad fish" symbols. Significant breakpoints in the compositional data, as determined by multiple regression tree (MRT) analysis (see "Methods" section), are marked as arrows. Dates of breakpoints are as follows: Barningham-macrophytes (1928), Invertebrates (1944, 1966, 1973), Chironomids (1966), Cladocera (1958, 1979, 1992), Pigments (1839, 1984), Diatoms (1941) and Wolterton-macrophytes (1903), Invertebrates (1968), Chironomids (1973), Cladocera (1973), Pigments (1924, 1980).

\section{Pre-kill Conditions}

To understand the response of the two study lakes to fish kills, a reconstruction of pre-kill ecosystem structure and development is required in addition to a consideration of other potential drivers of ecological change, especially eutrophication. In Barningham, sparse plant macro-remains, combined with dominance in the Cladocera by $B$. longirostris and low representation of plant-associated cladoceran taxa, strongly suggest a highly eutrophic, largely macrophyte-free lake with abundant zooplanktivorous fish prior to the early 1950s fish kill (Davidson and others 2010a). Consistent with this hypothesis, high percentages of the planktonic diatom C. dubius (Figure 9) suggest high pelagic productivity before the fish kills period. By contrast, in Wolterton, cladoceran, chironomid and plant macrofossils allude to a clear-water lake with a diverse and abundant aquatic vegetation prior to the mid-1970s fish decline, although compositional shifts afford evidence for progressive nutrient enrichment during the preceding century. Before the late 1800s, exceptionally high concentrations of Chara and Nitella spp. oospores suggest dense charophyte lawns in Wolterton Lake, a situation typical of low-nutrient European shallow lakes during this era (Sayer and others 2010b, 2012; Baastrup-Spohr and others 2013). After 1900, however, a decline in charophyte remains and increases in macrofossils of $C$. demersum and $R$. sect. Batrachium signal plant structural changes typical of eutrophication and a declining light climate (Sayer and others 2010b). Equally, concomitant increases of colonial cyanobacteria (aphanizophyll, myxoxanthophyll, canthaxanthin) and of filter-feeding bryozoans (Plumatella spp. and $C$. 
mucedo), combined with declines in the plantdwelling zooplankters Camptocerus rectirostris and Alonella nana, are consistent with increasing pelagic relative to benthic primary production (Hartikainen and others 2009; Davidson and others 2011). Thus, although Wolterton was macrophyte dominated prior to the 1970s fish kill, it was likely already on a trajectory of progressive eutrophication.

\section{Trophic Cascade Response to Fish Kills}

It was hypothesised that fish kills would result in strong trophic cascade effects on biological structure which would be temporary in Barningham (due to fish re-colonisation) and permanent in Wolterton (due to a failure of fish to recolonise). Clear-cut and mostly predictable changes to cladoceran species assembly and body size were evident in both lakes. Large-bodied Daphnia abundance increased rapidly following fish declines indicative of much reduced predation pressure on pelagic zooplankton. In Wolterton, $D$. hyalina agg. and $D$. magna increased in a synchronous manner after the early 1970s fish kill. By contrast, in Barningham, whereas $D$. hyalina agg. increased following the early 1950s kill, D. magna did not increase until after the late 1970s kill. D. magna tends to dominate in shallow lakes where fish populations are low and macrophytes are sparse (Lauridsen and Lodge 1996; Davidson and others 2010a). This was likely the case in Barningham in the late 1970s with the macrofossils suggesting a major decline of $C$. demersum and Potamogeton spp. from c. 1972 onwards. Further, a more complete fish loss in the late 1970s may have especially promoted $D$. magna (see previous discussion). In parallel with Daphnia increases after the early 1950s, the smaller pelagic B. longirostris underwent a substantial decline undoubtedly due to increased interspecific competition. This shift from small to large cladoceran species is consistent with a classic size structure response to lowered zooplanktivory as predicted by the size efficiency hypothesis (Brooks and Dodson 1965). Indeed, similar changes have been recorded in other shallow lakes following fish kills and biomanipulations (Jeppesen and others 1998; Meijer and others 1999; Hobbs and others 2012).

Compared to the zooplankton, the response of invertebrates to changing fish populations in shallow lakes is less well understood in the scientific literature. Some studies have suggested that trophic cascade effects of fish on invertebrates are dampened in species-rich, macrophyte-dominated lakes due to diverse feeding pathways (which lowers interaction strength), combined with high structural complexity resulting in reduced foraging efficiency (Diehl 1988; Pierce and Hinrichs 1997). Following this argument, it might be expected that fish kill influence on invertebrates would be more strongly evident in macrophyte-poor Barningham compared to speciose, macrophyte-dominated Wolterton. By contrast, two previous field investigations in English shallow lakes, which included Wolterton as a study site (Jones and Sayer 2003; Beresford and Jones 2010), have revealed strong influences of fish on invertebrates under conditions of macrophyte dominance. In support of the latter idea, we show major increases in invertebrate abundances coincident with fish loss covering both pelagic (Chaoborus sp.) and epi-benthic (for example, Mollusca, Trichoptera, Ephemeroptera) species regardless of pre-fish kill macrophyte abundance: low in Barningham before the early 1950s kill and high in Wolterton prior to the early 1970s kill. It should be noted, however, that 1950s increases in invertebrates in Barningham (especially Mollusca) might also be strongly linked to increases in macrophyte coverage (as opposed to reduced predation) following fish loss (Figure 7A), with this significantly enhancing habitat availability. It is not possible to definitively separate these two potential causes, but low abundances of invertebrates after the early 1970s kill, when macrophytes were absent, suggest that habitat was a key driver of invertebrate change. Thus, fish kill influence on invertebrates was likely partly indirect in Barningham.

Although a significant change was evident in Wolterton, in contrast to the other invertebrates, the response of chironomids to fish kills was comparatively dampened and less clear-cut in Barningham Lake (Figures 5, 10). Possibly, this may relate to an overall preference of fish for larger invertebrates and not for small-bodied chironomids. A similar pattern was recorded in enclosure experiments by Beresford and Jones (2010) where fish guts contained high abundances of larger more motile Gastropoda, Ephemeroptera and Odonata, with lower numbers of smaller Chironomidae and Oligochaeta. Further, in a study of controls over chironomid composition in surface sediments from shallow lakes with strong measured nutrient, macrophyte and fish predation gradients, fish had a negligible influence over species assembly with macrophyte diversity/abundance and TP more important (Langdon and others 2010). It seems likely, therefore, that background eutrophication forcing was a key overriding driver of Barningham 
chironomid changes possibly linked to changes in benthic habitat structure and oxygen status.

At the phytoplankton level, theory would predict a reduction in pelagic algal abundance following fish declines due to enhanced grazing and/or increased phosphorus storage in the zooplankton associated with increases in large cladocerans (Vanni and Layne 1997). Although our data do suggest changes to phytoplankton abundance and composition following the fish kills, it is not possible to separate the relative influences of direct grazing versus changes in nutrient storage. Interestingly, planktonic diatoms (especially C. dubius) showed a substantial reduction in the mid-1940s just prior to the 1950s fish kill (Figure 9) potentially suggesting a pre-kill reduction in eutrophication development. Nevertheless, the kill coincided with a further decrease in C. dubius and a parallel (although nonsignificant) shift in the diatom PC (Figure 10A). Despite a loss of macrophytes after c. 1972 and a recovery of fish by the late 1980s, planktonic diatoms failed to make a major return, although moderate increases were evident after the mid1980s and the pattern of $C$. dubius change generally closely followed that of $B$. longirostris suggesting a strong fish-zooplankton-diatom cascade. Diatom data were not available for Wolterton, but reductions in planktonic algae are suggested, albeit indirectly, by post-kill declines in filter-feeding bryozoans (Plumatella sp. and C. mucedo-see Figure $4 \mathrm{~B}$ ) indicative of substantially reduced phytoplankton food (Hartikainen and others 2009).

The pigment data suggest other important algal compositional shifts linked to the fish kills (Figure 8). In both lakes, fish absence was associated with increases in cyanobacterial pigments with a bulge of myxoxanthophyll and lutein-zeaxanthin in Barningham during the fish kills period and increases in echinenone, myxoxanthophyll and aphanizophyll evident in Wolterton following the 1970s kill. This finding contradicts with most biomanipulation studies where fish reduction has generally been accompanied by increases in small fast-growing algae (for example, cryptophytes) and declines in cyanobacteria linked to high predation on larger algae (Søndergaard and other 2008). A likely explanation for this pattern is a size refugia effect whereby blue-green algae (especially colonial species) are promoted by high Daphnia grazing due to their relative inedibility, compared to other pelagic algae (Jones and Jeppesen 2007; Gulati and others 2008). Supporting this, observation field investigations revealed bloom-forming populations of Aphanizomenon sp. in fish-free Wolterton during 1999-2000 (Sayer and others 2010c).

\section{Sequencing and Permanence of Fish Kill} Effects?

In Wolterton, the permanent loss of fish in the early 1970s led to a persistent change (until present) in the ecosystem characterised by much higher abundances of plant-associated invertebrates, large-bodied Cladocera and likely dominance of Chaoborus sp. as an open-water predator. In Barningham, following the early 1950s kill, fish populations were low and our data suggest that macrophytes quickly colonised and were abundant until about 1972 after which a decline is signalled by reductions in remains of $C$. demersum and plantassociated invertebrates. This loss of macrophytes occurred before any major return of fish, as would have been apparent in the cladoceran data. Thus, macrophytes persisted for around 20 years following the first fish kill, but eventually declined suggesting that, even in the absence of fish, underlying eutrophication was sufficient to induce a loss of aquatic vegetation. In contrast to the 1950s kill, there was no evidence for a return of macrophytes after the late 1970s kill, the explanation for which is indeterminable from our palaeo-data and thus open for debate. Nevertheless, an inconsistent response of macrophytes to biomanipulation-induced fish removal has often been observed in shallow eutrophic lakes (Gulati and others 2008; Jeppesen and others 2012). Certainly, some 8-10 years after the late 1970s kill, fish populations started to recover in Barningham as indicated by declines in $D$. magna in the late 1980s. It is possible that a recovery of macrophytes at this stage was hindered by a more rapid return of fish and/or possibly further development of eutrophication. By the late 1990s, a rise in B. longirostris back to pre-1950s fish kill levels likely signals a substantial fish population. Therefore, as hypothesised, while fish kill effects on lake ecology were permanent in Wolterton, due to a lack of fish recovery, Barningham, at least after the first kill, behaved in an "elastic way" with the recovery of fish leading to a relatively rapid reversion back to turbid, eutrophic conditions. Certainly, given highly eutrophic conditions in Barningham Lake a quick loss of plants would be expected.

\section{Implications for Theory and Lake Restoration}

In a review of many European biomanipulation studies, Søndergaard and others (2008) concluded that, due to a relatively rapid post-manipulation recolonisation of fish, most lake variables showed 
short-lived change (generally $<10$ years), and in general, although aquatic vegetation frequently returned following fish removal, it declined or was lost altogether as fish populations recovered and high zooplanktivory resumed. Indeed, lasting effects of biomanipulation are thought to be only achieved where nutrient levels are low (perhaps less than around $50 \mu \mathrm{g} \mathrm{TP} \mathrm{I}^{-1}$ ) and where biomanipulation is repeated (Jeppesen and others 2012). The results from Barningham clearly confirm the short-term and highly temporary effects of fish removal impacts at high nutrient levels and also support the literature (for example, Gulati and others 2008) in confirming an inconsistent response of macrophyte to biomanipulation.

In Wolterton, despite clear evidence for increased zooplanktivory following the fish decline, there was no clear corresponding change to macrophyte communities. Alternatively, the Wolterton macrofossil data suggest a pattern of macrophyte change consistent with centennial-scale eutrophication. The transition from charophytes/M. spicatum (c. pre-1890), to Ceratophyllum/Ranunculus (early-mid twentieth century) and finally to Z. palustris/fineleaved Potamogeton (late 1970s) dominance is commonly documented in European shallow lakes affected by nutrient enrichment. In particular, the latter shift to Potamogeton-Zannichellia is an often observed eutrophication 'end stage' (Sayer and others 2010b; Hilt and others 2013; Bennion and others 2015), characterised by a short summer phase of high macrophyte coverage, followed by macrophyte decline in late summer and high phytoplankton abundances (Sayer and others 2010c). Indeed, lakes in this situation are thought to be more similar in function to turbid, plant-free lakes than to high-diversity macrophyte-dominated lakes (Sayer and others 2010c; Davidson and others 2010a). Thus, even in the absence of fish and any significant grazing on large cladocerans, it appears that eutrophication continued to exert a strong negative influence on macrophytes in Wolterton Lake. Other signals in the Wolterton palaeo-record support this hypothesis, including increases in $B$. longirostris prior to and following the early 1970s fish kill suggesting increases in pelagic chlorophyll a (Davidson and others 2010a, b). Thus, although fish disappearance may have slowed down the eutrophication process, it was not able to halt it in the long term.

\section{Conclusions}

Our study is unique in showing fish loss effects for macrophyte-dominated and macrophyte-free lakes across multiple trophic levels and covering a longer timescale than even the most long term of shallow lake monitoring studies. Important implications for lake restoration ecology and ecological theory arise from this study. Firstly, it is evident from both lakes that restoration needs to tackle eutrophication as the absolute priority to achieve sustainable results, that is, higher macrophyte diversity and ideally macrophyte dominance over long periods of the year (Sayer and others 2010c; Hilt and others 2013). Indeed, similar to recent reviews, this study suggests that biomanipulation is only a sustainable lake restoration tool where background eutrophication issues have already been tackled. Secondly, this study supports the idea that eutrophicationdriven loss of macrophytes is a slow, progressive process in shallow lakes (for example, Sayer and others $2010 \mathrm{~b}, \mathrm{c})$ such that perturbations and regime shifts are not necessary pre-cursors to macrophyte loss. In this respect, fish kills and fish re-colonisations can be seen as superimposed perturbations which temporarily disturb (as at Barningham) or potentially slow down (as at Wolterton) eutrophication trajectories, but do not significantly change the destination, namely eutrophic conditions and phytoplankton dominance. In this sense, it is evident that the relative importance of top-down (fish) versus bottom-up (nutrients) forcing of community change depends on temporal scale, with the latter of greater importance in the long term. Our study highlights the enormous potential of multi-indicator palaeolimnology for inferring long-term ecological change linked to changing fish communities in shallow lakes.

\section{ACKNOWLEDGEMENTS}

The authors would like to thank Lord and Lady Walpole and Thomas and Amelia Courthauld for site access. We thank June and Derek Sayer for accommodation and Ben Goldsmith, Chris and Helen Goldsmith and Genevieve Madgwick for assistance with fieldwork. Thanks are also due to Cath D'alton for drawing the figures and John Rogers, John Bailey, Chris Turnball and Stephen Harper for information on the fish histories of Barningham and Wolterton Lakes. This research was funded by a Natural Environment Research Council (NERC) grant to Carl Sayer and Thomas Davidson (Grant Code: NE/D008344/1). We dedicate this paper to the late Lady Stella Mott-Ratclyffe who inspired the project by showing Carl Sayer and Thomas Davidson the Figure 1 photograph in 1998. 


\section{OPEN ACCESS}

This article is distributed under the terms of the Creative Commons Attribution 4.0 International License (http://creativecommons.org/licenses/by/4.0/), which permits unrestricted use, distribution, and reproduction in any medium, provided you give appropriate credit to the original author(s) and the source, provide a link to the Creative Commons license, and indicate if changes were made.

\section{REFERENCES}

Amsinck SL, Jeppesen E, Landkildehus F. 2005. Inference of past changes in zooplankton community structure and planktivorous fish abundance from sedimentary subfossils-a study of a coastal lake subjected to major fish kill incidents during the past century. Arch Hydrobiol 3:363-82.

Alonso M. 1996. Crustacea, Branchiopoda, Vol. 7Madrid: CSIC.

Appleby PG, Oldfield F. 1978. The calculation of ${ }^{210} \mathrm{~Pb}$ dates assuming a constant rate of supply of unsupported ${ }^{210} \mathrm{~Pb}$ to the sediment. Catena 5:1-8.

Appleby PG, Oldfield F. 1983. The assessment of ${ }^{210} \mathrm{~Pb}$ data from sites with varying sediment accumulation rates. Hydrobiologia 103:29-35.

Appleby PG. 2001. Chronostratigraphic techniques in recent sediments. In: Last WM, Smol JP, Eds. Tracking environmental change using lake sediments. Vol. 1: basin analysis, coring, and chronological techniques. Dordrecht (The Netherlands): Kluwer Academic Publishers. p 171-203.

Baastrup-Spohr L, Iversen LL, Dahl-Nielsen J, Sand-Jensen KJ. 2013. Seventy years of changes in the abundance of Danish charophytes. Freshw Biol 58:1682-93.

Bailey J. 1984. In visible waters. Ramsbury (UK): The Crowood Press.

Bailey J. 1987. Reflections from the Waters Edge. Ramsbury (UK): The Crowood Press.

Balayla D, Lauridsen TL, Søndergaard M, Jeppesen E. 2010. Larger zooplankton in Danish lakes after cold winters: are winter fish kills of importance? Hydrobiologia 649:159-72.

Battarbee RW, Jones VJ, Flower RJ, Cameron NG, Bennion H, Carvalho L, Juggins S. 2001. Diatoms. In: Smol JP, Birks HJB, Last WM, Eds. Tracking environmental change using lake sediments. Vol. 3: terrestrial, algal, and siliceous indicators. Dordrecht (The Netherlands): Kluwer Academic Publishers. p 155-202.

Bennion H, Davidson TA, Sayer CD, Simpson GL, Rose NL, Sadler JP. 2015. Harnessing the potential of the multi-indicator palaeoecological approach: an assessment of the nature and causes of ecological change in a eutrophic shallow lake. Freshw Biol 60:1423-42.

Beresford AL, Jones JI. 2010. Weedbeds and big bugs; the importance of scale in detecting the influence of nutrients and predation on macroinvertebrates in plant dominated shallow lakes. Freshw Biol 55:514-30.

Birks HH. 2001. Plant Macrofossils. In: Smol JP, Birks HJB, Last WM, Eds. Tracking environmental change using lake sediments. Vol. 3: terrestrial, algal, and siliceous indicators. Dordrecht (The Netherlands): Kluwer Academic Publishers. p 4974 .
Brodersen KP, Odgaard BV, Vestergaard O, Anderson NJ. 2001. Chironomid stratigraphy in the shallow and eutrophic Lake Søbygaard, Denmark: chironomid-macrophyte co-occurrence. Freshw Biol 46:253-67.

Brooks JL, Dodson SI. 1965. Predation, body size and composition of plankton. Science 150:28-35.

Brooks SJ, Langdon PG, Heiri O. 2007. The identification and use of palaearctic chironomidae larvae in palaeoecology. Quaternary Research Association Technical Guide No. 10. London: Quaternary Research Association.

Brönmark C, Weisner SEB. 1992. Indirect effects of fish community structure on submerged vegetation in shallow, eutrophic lakes-an alternative mechanism. Hydrobiologia 243:293-301.

Buchaca T, Skov T, Amsinck SL, Gonçalves V, Azevedo JMN, Andersen TJ, Jeppesen E. 2011. Rapid ecological shift following piscivorous fish introduction to increasingly eutrophic and warmer Lake Furnas (Azores Archipelago, Portugal): a palaeoecological approach. Ecosystems 14:458-77.

Carpenter SR, Kitchell JF, Hodgson JR. 1985. Cascading trophic interactions and lake productivity. Fish production and herbivory can regulate lake ecosystems. BioScience 35:634-9.

Carpenter SR, Lodge DM. 1986. Effects of submersed macrophytes on ecosystem processes. Aquat Bot 26:341-70.

Carpenter SR, Leavitt PR. 1991. Temporal variation in a paleolimnological record arising from a trophic cascade. Ecology 72:277-85.

Carvalho L. 1994. Top-down control of phytoplankton in a shallow hypertrophic lake: little Mere (England). Hydrobiologia 275-276:53-63.

Davidson TA, Sayer CD, Bennion H, David C, Rose N, Wade PM. 2005. A 250 year comparison of historical, macrofossil and pollen records of aquatic plants in a shallow lake. Freshw Biol 50:1671-86.

Davidson TA, Sayer CD, Perrow M, Bramm M, Jeppesen E. 2007. Are the controls of species composition similar for contemporary and sub-fossil cladoceran assemblages? A study of 39 shallow lakes of contrasting trophic status. J Paleolimnol 38:117-34.

Davidson TA, Sayer CD, Perrow M, Jeppesen E. 2010a. The simultaneous inference of zooplanktivorous fish and macrophyte density from sub-fossil cladoceran assemblages: a multivariate regression tree approach. Freshw Biol 55:546-64.

Davidson TA, Sayer CD, Langdon PG, Ruiz Z, Burgess A. 2010b. Inferring past zooplanktivorous fish and macrophyte density in a shallow lake: application of a new regression tree model. Freshw Biol 55:584-99.

Davidson TA, Bennion H, Sayer CD, Jeppesen E, Clarke GH, Morley D, Odgaard B, Rasmussen R, Rawcliffe R, Salgado J, Amsinck SL. 2011. The role of cladocerans in tracking longterm change in shallow lake ecosystem structure and function. Hydrobiologia 676:299-315.

Diehl S. 1988. Foraging efficiency of three freshwater fishes: effects of structural complexity and light. Oikos 53:207-14.

De'ath G. 1999. Principal curves: a new technique for indirect and direct gradient analysis. Ecology 80:2237-53.

De'ath G. 2002. Multivariate regression trees: a new technique for modeling species-environment relationships. Ecology 83:1105-17.

Flössner D. 1972. Krebstiere, Crustacea: Kienen- und Balttfüsser, Branchiopoda Fischläuse, Branchiura, Vol. 60Jena: Gustav Fisher Verlag. 
Frey D. 1958. The late-glacial cladoceran fauna of a small lake. Arch Hydrobiol 54:209-75.

Gulati RG, Pires LMD, van Donk E. 2008. Lake restoration studies: failures, bottlenecks and prospects of new ecotechnolohical measures. Limnologica 38:233-47.

Hartikainen H, Johnes P, Moncrieff C, Okamura B. 2009. Bryozoan populations reflect nutrient enrichment and productivity gradients in rivers. Freshw Biol 54:2320-34.

Hastie T, De'ath G, Walsh C. 2011. pcurve: principal curves analysis. http://CRAN.R-project.org/package=pcurve.

Hilt S, Köhler J, Adrian R, Monaghan MT, Sayer CD. 2013. Clear, crashing, turbid and back-long-term macrophyte changes in macrophyte assemblages in a shallow lake. Freshw Biol 58:2027-36.

Hobbs WO, Ramstack Hobbs JM, LaFrançois T, Zimmer KD, Theissen KM, Edlund MB, Michelutti N, Butler MG, Hanson MA, Thomas JC. 2012. A 200-year perspective on alternative stable state theory and lake management from a biomanipulated shallow lake. Ecol Appl 22:1483-96.

Jeppesen E, Leavitt PR, De Meester L, Jensen J. 2001. Functional ecology and palaeolimnology: using cladoceran remains to reconstruct anthropogenic impact. Trends Ecol Evol 16:191-8.

Jeppesen E, Søndergaard M, Jensen JP, Mortensen E, Hansen AM, Jørgensen T. 1998. Cascading trophic interactions from fish to bacteria and nutrients after reduced sewage loading: an 18 year study of a shallow hypertrophic lake. Ecosystems $1: 250-67$.

Jeppesen E, Søndergaard M, Lauridsen TL, Davidson TA, Liu Z, Mazzeo N, Trochine C, Özkan K, Jensen HS, Trolle D, Starling F, Lazzaro X, Johansson LS, Bjerring R, Liboriussen L, Larsen SE, Landkildehus F, Egemose S, Meerhoff M. 2012. Biomanipulation as a response tool to combat eutrophication: recent advances and future challenges. Adv Ecol Res 47:411-88.

Jones JI, Sayer CD. 2003. Does the fish-invertebrate-periphyton cascade precipitate plant loss in shallow lakes? Ecology $84: 2155-67$.

Jones JI, Jeppesen E. 2007. Body size and trophic cascades in lakes. In: Hildrew AG, Raffaelli DG, Edmonds-Brown R, Eds. The structure and function of aquatic ecosystems. Cambridge: Cambridge University Press p. p 118-39.

Korhola A, Rautio M. 2001. Cladocera and other branchiopod crustaceans. In: Smol JP, Birks HJB, Last WM, Eds. Tracking environmental change using lake sediments. Vol 4: zoological indicators. Dordrecht (The Netherlands): Kluwer Academic Publishers. p 5-41.

Langdon PG, Ruiz Z, Wynne S, Sayer CD, Davidson TA. 2010. Ecological influences on larval chironomid communities in shallow lakes: implications for palaeolimnological interpretations. Freshw Biol 55:531-45.

Lauridsen T, Lodge D. 1996. Avoidance by Daphnia magna of fish and macrophytes: chemical cues and predator-mediated use of macrophyte habitat. Limnol Oceanogr 41:794-8.

Leavitt PR, Carpenter SR, Kitchell JF. 1989. Whole-lake experiments: the annual record of fossil pigments and zooplankton. Limnol Oceanogr 34:700-17.

Leavitt PR, Hann BJ, Smol JP, Zeeb BA, Christie CE, Wolfe B, Kling HJ. 1994. Paleolimnological analysis of whole-lake experiments: an overview of results from Experimental Lakes Area Lake 227. Can J Fish Aquat Sci 51:2322-32.

Leavitt PR, Vinebrooke RD, Donald DB, Smol JP, Schindler DW. 1997. Past ultraviolet environments in lakes derived from fossil pigments. Nature 388:457-9.
Leavitt PR, Hodgson A. 2001. Sedimentary pigments. In: Smol JP, Birks HJB, Last WM, Eds. Tracking environmental change using lake sediments. Vol. 3: terrestrial, algal, and siliceous indicators. Dordrecht (The Netherlands): Kluwer Academic Publishers. p 295-325.

Legendre P, Gallagher ED. 2001. Ecologically meaningful transformations for ordination of species data. Oecologia 129:271-80.

Lewis JW, Morley NJ, Drinkall J, Jamieson BJ, Wright R, Parry JD. 2009. Toxic effects of Streptomyces griseus spores and exudate on gill pathology of freshwater fish. Ecotox Environ Safety 72:173-81.

Meijer M-L, Boois I, Scheffer M, Portielje R, Hosper H. 1999. Biomanipulation in shallow lakes in The Netherlands: an evaluation of 18 case studies. Hydrobiologia 408(408):13-30.

Miskimmen BM, Leavitt PR, Schindler DW. 1995. Fossil record of cladoceran and algal responses to fishery management practices. Freshw Biol 34:177-90.

Nykänen M, Malinen T, Vakkilainen K, Liukkonen M, Kairesalo T. 2009. Cladoceran community responses to biomanipulation and re-oligotrophication in Lake Vesijärvi, Finland, as inferred from remains in annually laminated sediment. Freshw Biol 55:1164-81.

Odgaard BV, Rasmussen P. 2001. The occurrence of egg-cocoons of the leech Piscicola geometra (L.) in recent lake sediments and their relationships with remains of submerged macrophytes. Arch Hydrobiol 152:671-86.

Patmore IR, Sayer CD, Goldsmith B, Davidson TA, Rawcliffe R, Salgado J. 2014. Big Ben: a new wide bore piston corer for multi-proxy paleolimnology. J Paleolimnol 51:79-86.

Pierce C, Hinrichs B. 1997. Response of littoral invertebrates to reduction of fish density: simultaneous experiments in ponds with different fish assemblages. Freshw Biol 37:397-408.

R Development Core Team. 2011. R: a language and environment for statistical computing. Vienna (Austria): R Foundation for Statistical Computing.

Rawcliffe R, Sayer CD, Woodward G, Grey J, Davidson TA, Jones JI. 2010. Back to the future: using palaeolimnology to infer long-term changes in shallow lake food webs. Freshw Biol 55:600-13.

Rose NL. 1994. A note on further refinements to a procedure for the extraction of carbonaceous fly-ash particles from sediments. J Paleolimnol 11:201-4.

Rose NL. 2008. Quality control in the analysis of lake sediments for spheroidal carbonaceous particles. Limnol Oceanogr Methods 6:172-9.

Rose NL, Appleby PG. 2005. Regional applications of lake sediment dating by spheroidal carbonaceous particle analysis I: United Kingdom. J Paleolimnol 34:349-61.

Rose NL, Harlock S, Appleby PG, Battarbee RW. 1995. The dating of recent lake sediments in the United Kingdom and Ireland using spheroidal carbonaceous particle concentration profiles. Holocene 5:328-35.

Ruiz Z, Brown AG, Langdon PG. 2006. The potential of chironomid (Insecta: Diptera) larvae in archaeological investigations of floodplain and lake settlements. J Archaeol Sci 33:14-33.

Sawyer RT. 1986. Leech biology and behaviour. Oxford: Oxford University Press.

Sayer CD, Davidson TA, Jones IJ, Langdon PG. 2010a. Combining contemporary ecology and palaeolimnology to understand shallow lake ecosystem change. Freshw Biol 55:487-99. 
Sayer CD, Burgess A, Kari K, Peglar S, Davidson TA, Yang H, Rose N. 2010b. Long-term dynamics of submerged macrophytes and algae in a small and shallow, eutrophic lake: implications for the stability of macrophyte-dominance. Freshw Biol 55:565-83.

Sayer CD, Davidson TA, Jones JI. 2010c. Seasonal dynamics of macrophytes and phytoplankton in shallow lakes: a eutrophication-driven pathway from plants to plankton. Freshw Biol 55:500-13.

Sayer CD, Bennion H, Davidson TA, Burgess A, Clarke G, Hoare D, Frings P, Hatton-Ellis T. 2012. The application of palaeolimnology to evidence-led lake management and conservation: examples from UK lakes. Aquat Conserv Mar Freshw Ecosyst 22:165-80.

Simpson G, Birks HJ. 2012. Statistical Learning in Palaeolimnology. In: Birks HJB, Lotter AF, Juggins S, Smol JP, Eds. Tracking environmental change using lake sediments. Vol. 5: data handling and numerical techniques. Springer: Dordrecht (The Netherlands). p 249-327.
Søndergaard M, Jeppesen E, Lauridsen TL, Skov C, Van Nes EH, Roijackers R, Lammens E, Portielje R. 2007. Lake restoration: successes, failures and long-term effects. J Appl Ecol 44:1095105.

Søndergaard M, Liboriussen L, Pedersen AR, Jeppesen E. 2008. Lake restoration by fish removal: short- and long-term effects in 36 Danish lakes. Ecosystems 11:1291-305.

Vanni MJ, Layne CD. 1997. Nutrient recycling and herbivory as mechanisms in the top-down effects of fish on algae in lakes. Ecology 78:21-40.

Vanni MJ, Layne CD, Arnott SE. 1997. Top down trophic interactions in lakes: effects of fish on nutrient dynamics. Ecology 78:1-20.

Zambrano L, Perrow MR, Sayer CD, Tomlinson ML, Davidson TA. 2006. Relationships between fish feeding guild and trophic structure in English lowland shallow lakes subject to anthropogenic influence: implications for lake restoration. Aquat Ecol 40:391-405. 